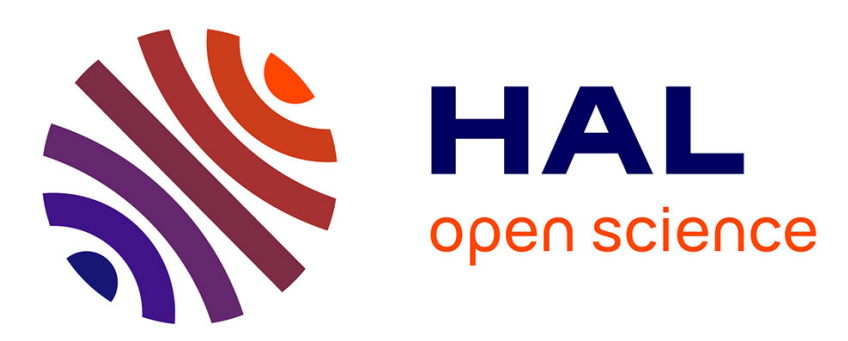

\title{
Joint assessment of brain and spinal cord motor tract damage in patients with early RRMS : predominant impact of spinal cord lesions on motor function
}

\author{
Raphaël Chouteau
}

\section{- To cite this version:}

Raphaël Chouteau. Joint assessment of brain and spinal cord motor tract damage in patients with early RRMS : predominant impact of spinal cord lesions on motor function. Life Sciences [q-bio]. 2019. dumas-02559046

\section{HAL Id: dumas-02559046 https://dumas.ccsd.cnrs.fr/dumas-02559046}

Submitted on 30 Apr 2020

HAL is a multi-disciplinary open access archive for the deposit and dissemination of scientific research documents, whether they are published or not. The documents may come from teaching and research institutions in France or abroad, or from public or private research centers.
L'archive ouverte pluridisciplinaire HAL, est destinée au dépôt et à la diffusion de documents scientifiques de niveau recherche, publiés ou non, émanant des établissements d'enseignement et de recherche français ou étrangers, des laboratoires publics ou privés. 
THÈSE D'EXERCICE / UNIVERSITÉ DE RENNES 1 sous le sceau de l'Université Bretagne Loire

Thèse en vue du

DIPLÔME D'ÉTAT DE DOCTEUR EN MÉDECINE présentée par

\section{Raphaël CHOUTEAU}

Né le 10/05/1989 à Rennes

Évaluation conjointe des lésions du tractus moteur du cerveau et de la moelle épinière chez les patients atteints de SEP débutante: impact prédominant des lésions de la moelle épinière sur la fonction motrice
Thèse soutenue à Rennes

Le 12/07/2019

devant le jury composé de :

Gilles EDAN

PU-PH CHU de Rennes/ président de jury

Benoit COMBES

PhD, Post doctorant + INRIA Rennes/ examinateur

Paul SAULEAU

PU-PH CHU de Rennes / examinateur

Jean-Christophe FERRE

PU-PH CHU de Rennes / examinateur Anne KERBRAT

$\mathrm{PH}-\mathrm{U} \mathrm{CHU}$ de Rennes/ directrice de thèse 


\begin{tabular}{|c|c|c|c|}
\hline \multicolumn{4}{|c|}{ PROFESSEURS DES UNIVERSITES } \\
\hline NOM & PRENOM & TITRE & CNU \\
\hline ANNE-GALIBERT & Marie-Dominique & $\mathrm{PU}-\mathrm{PH}$ & $\begin{array}{l}\text { Biochimie et biologie } \\
\text { moléculaire }\end{array}$ \\
\hline BARDOU-JACQUET & Edouard & $\mathrm{PU}-\mathrm{PH}$ & $\begin{array}{l}\text { Gastroentérologie ; } \\
\text { hépatologie ; addictologie }\end{array}$ \\
\hline BELAUD-ROTUREAU & Marc-Antoine & PU-PH & $\begin{array}{l}\text { Histologie ; embryologie } \\
\text { et cytogénétique }\end{array}$ \\
\hline BELLISSANT & Eric & $\mathrm{PU}-\mathrm{PH}$ & $\begin{array}{l}\text { Pharmacologie } \\
\text { fondamentale ; } \\
\text { pharmacologie clinique ; } \\
\text { addictologie }\end{array}$ \\
\hline BELOEIL & Hélène & $\mathrm{PU}-\mathrm{PH}$ & $\begin{array}{l}\text { Anesthésiologie- } \\
\text { réanimation et médecine } \\
\text { péri-opératoire }\end{array}$ \\
\hline BENDAVID & Claude & $\mathrm{PU}-\mathrm{PH}$ & $\begin{array}{l}\text { Biochimie et biologie } \\
\text { moléculaire }\end{array}$ \\
\hline BENSALAH & Karim & PU-PH & Urologie \\
\hline BEUCHEE & Alain & PU-PH & Pédiatrie \\
\hline BONAN & Isabelle & $\mathrm{PU}-\mathrm{PH}$ & $\begin{array}{l}\text { Médecine physique et de } \\
\text { réadaptation }\end{array}$ \\
\hline BONNET & Fabrice & $\mathrm{PU}-\mathrm{PH}$ & $\begin{array}{l}\text { Endocrinologie, diabète } \\
\text { et maladies métaboliques } \\
\text {; gynécologie médicale }\end{array}$ \\
\hline BOUDJEMA & Karim & $\mathrm{PU}-\mathrm{PH}$ & Chirurgie générale \\
\hline BOUGET & Jacques & Pr Emérite & $\begin{array}{l}\text { Thérapeutique-médecine } \\
\text { de la douleur; } \\
\text { addictologie }\end{array}$ \\
\hline BOUGUEN & Guillaume & PU-PH & $\begin{array}{l}\text { Gastroentérologie ; } \\
\text { hépatologie ; addictologie }\end{array}$ \\
\hline BRASSIER & Gilles & $\mathrm{PU}-\mathrm{PH}$ & Neurochirurgie \\
\hline BRISSOT & Pierre & Pr Emérite & $\begin{array}{l}\text { Gastroentérologie ; } \\
\text { hépatologie ; addictologie }\end{array}$ \\
\hline CARRE & François & PU-PH & Physiologie \\
\hline CATROS & Véronique & PU-PH & Biologie cellulaire \\
\hline CATTOIR & Vincent & PU-PH & $\begin{array}{l}\text { Bactériologie-virologie ; } \\
\text { hygiène hospitalière }\end{array}$ \\
\hline CHALES & Gérard & Pr Emérite & Rhumatologie \\
\hline CORBINEAU & Hervé & $\mathrm{PU}-\mathrm{PH}$ & $\begin{array}{l}\text { Chirurgie thoracique et } \\
\text { cardiovasculaire }\end{array}$ \\
\hline CUGGIA & Marc & PU-PH & $\begin{array}{l}\text { Biostatistiques, } \\
\text { informatique médicale et } \\
\text { technologies de } \\
\text { communication }\end{array}$ \\
\hline DARNAULT & Pierre & PU-PH & Anatomie \\
\hline DAUBERT & Jean-Claude & Pr Emérite & Cardiologie \\
\hline DAVID & Véronique & $\mathrm{PU}-\mathrm{PH}$ & $\begin{array}{l}\text { Biochimie et biologie } \\
\text { moléculaire }\end{array}$ \\
\hline DAYAN & Jacques & Pr Associé & $\begin{array}{l}\text { Pédopsychiatrie ; } \\
\text { Addictologie }\end{array}$ \\
\hline DE CREVOISIER & Renaud & $\mathrm{PU}-\mathrm{PH}$ & $\begin{array}{l}\text { Cancérologie ; } \\
\text { radiothérapie }\end{array}$ \\
\hline DECAUX & Olivier & PU-PH & $\begin{array}{l}\text { Médecine interne; } \\
\text { gériatrie et biologie du } \\
\text { vieillissement; } \\
\text { addictologie }\end{array}$ \\
\hline DESRUES & Benoît & $\mathrm{PU}-\mathrm{PH}$ & $\begin{array}{l}\text { Pneumologie ; } \\
\text { addictologie }\end{array}$ \\
\hline
\end{tabular}




\begin{tabular}{|c|c|c|c|}
\hline DEUGNIER & Yves & Pr Emérite & $\begin{array}{l}\text { Gastroentérologie ; } \\
\text { hépatologie ; addictologie }\end{array}$ \\
\hline DONAL & Erwan & PU-PH & Cardiologie \\
\hline DRAPIER & Dominique & $\mathrm{PU}-\mathrm{PH}$ & $\begin{array}{l}\text { Psychiatrie d'adultes; } \\
\text { addictologie }\end{array}$ \\
\hline DUPUY & Alain & PU-PH & Dermato-vénérologie \\
\hline ECOFFEY & Claude & $\mathrm{PU}-\mathrm{PH}$ & $\begin{array}{l}\text { Anesthésiologie- } \\
\text { réanimation et médecine } \\
\text { péri-opératoire }\end{array}$ \\
\hline EDAN & Gilles & PU-PH consultant & Neurologie \\
\hline FERRE & Jean-Christophe & $\mathrm{PU}-\mathrm{PH}$ & $\begin{array}{l}\text { Radiologie et imagerie } \\
\text { médicale }\end{array}$ \\
\hline FEST & Thierry & PU-PH & Hématologie ; transfusion \\
\hline FLECHER & Erwan & $\mathrm{PU}-\mathrm{PH}$ & $\begin{array}{l}\text { Chirurgie thoracique et } \\
\text { cardiovasculaire }\end{array}$ \\
\hline GANDEMER & Virginie & PU-PH & Pédiatrie \\
\hline GANDON & Yves & $\mathrm{PU}-\mathrm{PH}$ & $\begin{array}{l}\text { Radiologie et imagerie } \\
\text { médicale }\end{array}$ \\
\hline GANGNEUX & Jean-Pierre & $\mathrm{PU}-\mathrm{PH}$ & $\begin{array}{l}\text { Parasitologie et } \\
\text { mycologie }\end{array}$ \\
\hline GARIN & Etienne & $\mathrm{PU}-\mathrm{PH}$ & $\begin{array}{l}\text { Biophysique et médecine } \\
\text { nucléaire }\end{array}$ \\
\hline GAUVRIT & Jean-Yves & $\mathrm{PU}-\mathrm{PH}$ & $\begin{array}{l}\text { Radiologie et imagerie } \\
\text { médicale }\end{array}$ \\
\hline GODEY & Benoît & PU-PH & Oto-rhino-laryngologie \\
\hline GUGGENBUHL & Pascal & PU-PH & Rhumatologie \\
\hline GUILLE & François & PU-PH & Urologie \\
\hline GUYADER & Dominique & PU-PH & $\begin{array}{l}\text { Gastroentérologie ; } \\
\text { hépatologie ; addictologie }\end{array}$ \\
\hline HAEGELEN & Claire & PU-PH & Anatomie \\
\hline HOUOT & Roch & PU-PH & Hématologie ; transfusion \\
\hline JEGO & Patrick & $\mathrm{PU}-\mathrm{PH}$ & $\begin{array}{l}\text { Médecine interne ; } \\
\text { gériatrie et biologie du } \\
\text { vieillissement ; } \\
\text { addictologie }\end{array}$ \\
\hline JEGOUX & Franck & PU-PH & Oto-rhino-laryngologie \\
\hline JOUNEAU & Stéphane & $\mathrm{PU}-\mathrm{PH}$ & $\begin{array}{l}\text { Pneumologie } \\
\text { addictologie }\end{array}$ \\
\hline KAYAL & Samer & PU-PH & $\begin{array}{l}\text { Bactériologie-virologie } \\
\text { hygiène hospitalière }\end{array}$ \\
\hline LAMY DE LA CHAPELLE & Thierry & PU-PH & Hématologie ; transfusion \\
\hline LAVIOLLE & Bruno & PU-PH & $\begin{array}{l}\text { Pharmacologie } \\
\text { fondamentale ; } \\
\text { pharmacologie clinique ; } \\
\text { addictologie }\end{array}$ \\
\hline LAVOUE & Vincent & PU-PH & $\begin{array}{l}\text { Gynécologie-obstétrique; } \\
\text { gynécologie médicale }\end{array}$ \\
\hline LE BRETON & Hervé & $\mathrm{PU}-\mathrm{PH}$ & Cardiologie \\
\hline LE GUEUT & Mariannick & PU-PH consultant & $\begin{array}{l}\text { Médecine légale et droit } \\
\text { de la santé }\end{array}$ \\
\hline LE TULZO & Yves & PU-PH & $\begin{array}{l}\text { Médecine intensive- } \\
\text { réanimation }\end{array}$ \\
\hline LECLERCQ & Christophe & PU-PH & Cardiologie \\
\hline LEDERLIN & Mathieu & PU-PH & $\begin{array}{l}\text { Radiologie et imagerie } \\
\text { médicale }\end{array}$ \\
\hline LEGUERRIER & Alain & Pr Emérite & $\begin{array}{l}\text { Chirurgie thoracique et } \\
\text { cardiovasculaire }\end{array}$ \\
\hline LEJEUNE & Florence & PU-PH & $\begin{array}{l}\text { Biophysique et médecine } \\
\text { nucléaire }\end{array}$ \\
\hline LEVEQUE & Jean & PU-PH & $\begin{array}{l}\text { Gynécologie-obstétrique } \\
\text { gynécologie médicale }\end{array}$ \\
\hline
\end{tabular}




\begin{tabular}{|c|c|c|c|}
\hline LIEVRE & Astrid & PU-PH & $\begin{array}{l}\text { Gastroentérologie ; } \\
\text { hépatologie ; addictologie }\end{array}$ \\
\hline MABO & Philippe & PU-PH & Cardiologie \\
\hline MAHE & Guillaume & PU-PH & $\begin{array}{l}\text { Chirurgie vasculaire ; } \\
\text { médecine vasculaire }\end{array}$ \\
\hline MALLEDANT & Yannick & Pr Emérite & $\begin{array}{l}\text { Anesthésiologie- } \\
\text { réanimation et médecine } \\
\text { péri-opératoire }\end{array}$ \\
\hline MENER & Eric & Pr Associé & Médecine générale \\
\hline MEUNIER & Bernard & PU-PH & Chirurgie digestive \\
\hline MICHELET & Christian & Pr Emérite & $\begin{array}{l}\text { Maladies infectieuses; } \\
\text { maladies tropicales }\end{array}$ \\
\hline MOIRAND & Romain & $\mathrm{PU}-\mathrm{PH}$ & $\begin{array}{l}\text { Gastroentérologie ; } \\
\text { hépatologie ; addictologie }\end{array}$ \\
\hline MORANDI & Xavier & PU-PH & Anatomie \\
\hline MOREL & Vincent & Pr Associé & Médecine palliative \\
\hline MOSSER & Jean & $\mathrm{PU}-\mathrm{PH}$ & $\begin{array}{l}\text { Biochimie et biologie } \\
\text { moléculaire }\end{array}$ \\
\hline MOURIAUX & Frédéric & PU-PH & Ophtalmologie \\
\hline MYHIE & Didier & Pr Associé & Médecine générale \\
\hline ODENT & Sylvie & PU-PH & Génétique \\
\hline OGER & Emmanuel & PU-PH & $\begin{array}{l}\text { Pharmacologie } \\
\text { fondamentale ; } \\
\text { pharmacologie clinique ; } \\
\text { addictologie }\end{array}$ \\
\hline PARIS & Christophe & $\mathrm{PU}-\mathrm{PH}$ & $\begin{array}{l}\text { Médecine et santé au } \\
\text { travail }\end{array}$ \\
\hline PERDRIGER & Aleth & PU-PH & Rhumatologie \\
\hline PLADYS & Patrick & PU-PH & Pédiatrie \\
\hline RAVEL & Célia & $\mathrm{PU}-\mathrm{PH}$ & $\begin{array}{l}\text { Histologie, embryologie } \\
\text { et cytogénétique }\end{array}$ \\
\hline REVEST & Matthieu & PU-PH & $\begin{array}{l}\text { Maladies infectieuses; } \\
\text { maladies tropicales }\end{array}$ \\
\hline RICHARD DE LATOUR & Bertrand & Pr Associé & $\begin{array}{l}\text { Chirurgie thoracique et } \\
\text { cardiovasculaire }\end{array}$ \\
\hline RIFFAUD & Laurent & PU-PH & Neurochirurgie \\
\hline RIOUX-LECLERCQ & Nathalie & $\mathrm{PU}-\mathrm{PH}$ & $\begin{array}{l}\text { Anatomie et cytologie } \\
\text { pathologiques }\end{array}$ \\
\hline ROBERT-GANGNEUX & Florence & PU-PH & $\begin{array}{l}\text { Parasitologie et } \\
\text { mycologie }\end{array}$ \\
\hline ROPARS & Mickaël & $\mathrm{PU}-\mathrm{PH}$ & $\begin{array}{l}\text { Chirurgie orthopédique et } \\
\text { traumatologique }\end{array}$ \\
\hline SAINT-JAMES & Hervé & PU-PH & $\begin{array}{l}\text { Biophysique et médecine } \\
\text { nucléaire }\end{array}$ \\
\hline SAULEAU & Paul & PU-PH & Physiologie \\
\hline SEGUIN & Philippe & PU-PH & $\begin{array}{l}\text { Anesthésiologie- } \\
\text { réanimation et médecine } \\
\text { péri-opératoire }\end{array}$ \\
\hline SEMANA & Gilbert & PU-PH & Immunologie \\
\hline SIPROUDHIS & Laurent & PU-PH & $\begin{array}{l}\text { Gastroentérologie ; } \\
\text { hépatologie ; addictologie }\end{array}$ \\
\hline SOMME & Dominique & PU-PH & $\begin{array}{l}\text { Médecine interne; } \\
\text { gériatrie et biologie du } \\
\text { vieillissement; } \\
\text { addictologie }\end{array}$ \\
\hline SOULAT & Louis & Pr Associé & Médecine d'urgence \\
\hline SULPICE & Laurent & PU-PH & Chirurgie générale \\
\hline TADIE & Jean Marc & $\mathrm{PU}-\mathrm{PH}$ & $\begin{array}{l}\text { Médecine intensive- } \\
\text { réanimation }\end{array}$ \\
\hline TARTE & Karin & PU-PH & Immunologie \\
\hline TATTEVIN & Pierre & PU-PH & Maladies infectieuses; \\
\hline
\end{tabular}


TATTEVIN-FABLET

THIBAULT

THIBAULT

THOMAZEAU

TORDJMAN

VERHOYE

VERIN

VIEL

VIGNEAU

VIOLAS

WATIER

WODEY
Françoise

Ronan

Vincent

Hervé

Sylvie

Jean-Philippe

Marc

Jean-François

Cécile

Philippe

Eric

Eric

PU-PH maladies tropicales

Médecine générale

Nutrition

Bactériologie-virologie ;

hygiène hospitalière

Chirurgie orthopédique et

traumatologique

Pédopsychiatrie ;

addictologie

Chirurgie thoracique et

cardiovasculaire

Neurologie

Epidémiologie, économie

de la santé et prévention

Néphrologie

Chirurgie infantile

Chirurgie plastique,

reconstructrice et

esthétique ; brûlologie

Anesthésiologie-

réanimation et médecine

péri-opératoire 


\section{6}

MAITRES DE CONFERENCES DES UNIVERSITES

\begin{tabular}{|c|c|c|c|}
\hline NOM & PRENOM & TITRE & CNU \\
\hline ALLORY & Emmanuel & MC Associé & Médecine générale \\
\hline AME-THOMAS & Patricia & MCU-PH & Immunologie \\
\hline AMIOT & Laurence & MCU-PH & Hématologie ; transfusion \\
\hline ANSELMI & Amédéo & MCU-PH & $\begin{array}{l}\text { Chirurgie thoracique et } \\
\text { cardiovasculaire }\end{array}$ \\
\hline BEGUE & Jean Marc & MCU-PH & Physiologie \\
\hline BERTHEUIL & Nicolas & MCU-PH & $\begin{array}{l}\text { Chirurgie plastique, } \\
\text { reconstructrice et } \\
\text { esthétique ; brûlologie }\end{array}$ \\
\hline BOUSSEMART & Lise & MCU-PH & Dermato-vénéréologie \\
\hline BROCHARD & Charlène & MCU-PH & Physiologie \\
\hline CABILLIC & Florian & MCU-PH & Biologie cellulaire \\
\hline CAUBET & Alain & MCU-PH & $\begin{array}{l}\text { Médecine et santé au } \\
\text { travail }\end{array}$ \\
\hline CHHOR-QUENIART & Sidonie & MC Associé & Médecine générale \\
\hline DAMERON & Olivier & MCF & Informatique \\
\hline DE TAYRAC & Marie & MCU-PH & $\begin{array}{l}\text { Biochimie et biologie } \\
\text { moléculaire }\end{array}$ \\
\hline DEGEILH & Brigitte & MCU-PH & Parasitologie et mycologie \\
\hline DROITCOURT & Catherine & MCU-PH & Dermato-vénéréologie \\
\hline DUBOURG & Christèle & MCU-PH & $\begin{array}{l}\text { Biochimie et biologie } \\
\text { moléculaire }\end{array}$ \\
\hline DUGAY & Frédéric & MCU-PH & $\begin{array}{l}\text { Histologie, embryologie et } \\
\text { cytogénétique }\end{array}$ \\
\hline EDELINE & Julien & MCU-PH & $\begin{array}{l}\text { Cancérologie } \\
\text { radiothérapie }\end{array}$ \\
\hline FIQUET & Laure & MC Associé & Médecine générale \\
\hline GARLANTEZEC & Ronan & MCU-PH & $\begin{array}{l}\text { Epidémiologie, économie } \\
\text { de la santé et prévention }\end{array}$ \\
\hline GOUIN épouse THIBAULT & Isabelle & MCU-PH & Hématologie ; transfusion \\
\hline GUILLET & Benoit & MCU-PH & Hématologie ; transfusion \\
\hline JAILLARD & Sylvie & MCU-PH & $\begin{array}{l}\text { Histologie, embryologie et } \\
\text { cytogénétique }\end{array}$ \\
\hline KALADJI & Adrien & MCU-PH & $\begin{array}{l}\text { Chirurgie vasculaire } \\
\text { médecine vasculaire }\end{array}$ \\
\hline KAMMERER-JACQUET & Solène-Florence & MCU-PH & $\begin{array}{l}\text { Anatomie et cytologie } \\
\text { pathologiques }\end{array}$ \\
\hline LAVENU & Audrey & MCF & $\begin{array}{l}\text { Sciences physico- } \\
\text { chimiques et ingénierie } \\
\text { appliquée à la santé }\end{array}$ \\
\hline LE GALL & François & MCU-PH & $\begin{array}{l}\text { Anatomie et cytologie } \\
\text { pathologiques }\end{array}$ \\
\hline LE GALL & Vanessa & MC Associé & Médecine générale \\
\hline LEMAITRE & Florian & MCU-PH & $\begin{array}{l}\text { Pharmacologie } \\
\text { fondamentale ; } \\
\text { pharmacologie clinique ; } \\
\text { addictologie }\end{array}$ \\
\hline MARTINS & Pédro Raphaël & MCU-PH & Cardiologie \\
\hline MATHIEU-SANQUER & Romain & MCU-PH & Urologie \\
\hline MENARD & Cédric & MCU-PH & Immunologie \\
\hline MICHEL & Laure & MCU-PH & Neurologie \\
\hline MOREAU & Caroline & MCU-PH & $\begin{array}{l}\text { Biochimie et biologie } \\
\text { moléculaire }\end{array}$ \\
\hline MOUSSOUNI & Fouzia & MCF & Informatique \\
\hline NAUDET & Florian & MCU-PH & $\begin{array}{l}\text { Thérapeutique-médecine } \\
\text { de la douleur; } \\
\text { addictologie }\end{array}$ \\
\hline PANGAULT & Céline & MCU-PH & Hématologie ; transfusion \\
\hline
\end{tabular}


ROBERT Gabriel MCU-PH

Médecine générale

SCHNEL

Frédéric

MCU-PH

THEAUDIN épouse SALIOU Marie

MCU-PH

P'adultes

TURLIN

Bruno

MCU-PH

VERDIER épouse LORNE

Marie-Clémence

MCU-PH

ZIELINSKI

Agata

MCF

hysiologie

Neurologie

Anatomie et cytologie

pathologiques

Pharmacologie

fondamentale ;

pharmacologie clinique ;

addictologie

Philosophie 


\section{Remerciements}

Au Professeur EDAN, pour sa disponibilité et surtout son perpétuel enthousiasme,

Au Professeur SAULEAU, pour son apprentissage à la rigueur scientifique et professionnelle, Au Professeur FERRE, pour m'avoir accordé sa confiance pour ce projet,

$\mathrm{Au}$ Dr COMBES (PhD), pour sa curiosité et pour m'avoir patiemment initier à l'informatique,

Au Dr KERBRAT, pour son soutien constant et éclairé, en dépit des distances

\section{Dédicaces}

Au Professeur Marc VERIN pour m'avoir orienté vers la neurologie à la sortie des ECN,

Aux Docteurs KASSIOTIS et PINEL qui m'ont transmis leur passion du diagnostic,

A Thierry, Karine, Timothée, Rabab et Emmanuel pour m'avoir tant appris sur « le nerf » et «le muscle»,

À toute l'équipe «Visages », en particulier Élise, pour m'avoir aidé pendant de longues heures de galère devant « mon » Linux,

A mes parents, pour leur soutien sans faille tout au long de mes études et qui doivent se réjouir au terme de mes études...

A mon frère et à mes sœurs, à ma belle-sœur, à mon beau-frère, à mes neveux, à ma nièce, et à tous mes amis, qui me rappellent que le travail n'est pas toute la vie

A mes co-internes pour tous ces moments passés au travail mais surtout en dehors, certains sont d'ailleurs devenus de véritables amis

Et surtout merci à ma compagne Pauline, pour son amour, sa patience et ses encouragements 


\section{Table des matières}

II) Documents administratifs

> Liste des PU-PH et MCU-PH.

$>$ Remerciements et dédicaces

$>$ Table des matières.

$>$ Liste des documents annexes

$>$ Liste des illustrations

III) Corps de thèse.

> Page de titre

$>$ Introduction.

$>$ Méthode.

$>$ Résultats.

$>$ Discussion

$>$ Conclusion.

> Bibliographie.

$>$ Figures

$>$ Tableaux

IV) Documents annexes.

V) Résumé.
Pages 2-11

Page 3

Page 8

Page 9

Page 10

Page 11

Pages 12-40

Page 12

Page 13

Page 14

Page 18

Page 20

Page 22

Page 23

Page 26

Page 29

Pages 41-47

Page 48 


\section{Liste des documents annexes}

\begin{tabular}{|c|c|}
\hline Annexe 1: Appendix for MRI methodology & Pages 41-45 \\
\hline Annexe 2: Appendix for electrophysiology methodology & Pages 46-47 \\
\hline
\end{tabular}




\section{$\underline{\text { Liste des illustrations }}$}

\begin{tabular}{|c|c|}
\hline Figure 1: Study design. & Page 26 \\
\hline Figure 2: Example of spinal cord MRI in a patient with RMMS. & Page 27 \\
\hline Figure 3: Example of brain MRI in patient with RRMS. & Page 28 \\
\hline
\end{tabular}




\section{Joint assessment of brain and spinal cord motor tract}

\section{damage in patients with early RRMS: predominant impact of spinal cord lesions on motor function}

Raphaël Chouteau $^{1,2}$, Benoit Combès ${ }^{2}(\mathrm{PhD})$, Elise Bannier ${ }^{2,3}(\mathrm{PhD})$, Haykel Snoussi ${ }^{2}$, Jean Christophe Ferré ${ }^{2,3}$ (MD, PhD), Christian Barillot ${ }^{2}$ (PhD), Gilles Edan ${ }^{1,2,4}$ (MD, PhD), Paul Sauleau $^{5,6}(\mathrm{MD}, \mathrm{PhD})$, Anne Kerbrat (MD, PhD) $)^{1,2}$

${ }^{1}$ CHU Rennes, Neurology Department, Rennes, France;

${ }^{2}$ Univ Rennes, Inria, CNRS, Inserm, IRISA UMR 6074, Visages U1228, France;

${ }^{3}$ CHU Rennes, Radiology Department, Rennes, France;

${ }^{4}$ Plurithematic Clinical Investigation Center (CIC-P 1414), INSERM, Rennes, France;

${ }^{5}$ CHU Rennes, Neurophysiology Department, France;

${ }^{6}$ Behavior and Basal Ganglia research unit (EA4712), Rennes 1 University, Rennes, France. 


\section{Introduction}

The secondary progressive phenotype MS usually presents as a worsening pyramidal syndrome of both lower and upper limbs, suggesting strong corticospinal tracts (CST) involvement ${ }^{1}$. However, quantifying focal and diffuse CST damage from the motor cortex to the spinal cord (SC) using MRI presents data-acquisition and dataprocessing challenges. Thus, the whole CST has not yet been explored in patients with MS.

Conversely, a substantial number of studies have focused on the brain portion of the CST. Diffusion tensor imaging (DTI) is a tool of choice for this exploration, as it allows white-matter (WM) tracts to be extracted and tissue integrity to be characterized. In particular, DTI-derived metrics extracted from the brain CST have been shown to correlate to several clinical scores ${ }^{2,3,4}$. Moderate associations between motor function and $\mathrm{T} 2$ lesion volume in the CST have been reported ${ }^{5}$. Finally, CST T2 lesion volume has been shown to correlate with DTI metrics in normalappearing $\mathrm{CST}^{6}$, suggesting that focal damage plays a role in both the lesion and Wallerian degeneration.

By contrast, only a limited number of studies have evaluated the impact of CST damage in the SC. For a start, the precise location of the lesions had not been fully explored, owing to technical limitations ${ }^{7}$, including the small size of the WM tract in the SC and the need for systematic whole-cord axial acquisitions with high in-plane resolution and large coverage ${ }^{7}$. Nevertheless, even without a specific assessment of lesion location, the SC T2 lesion load has been shown to be associated with disability ${ }^{8}$, and to have a strong prognostic value $e^{9,10}$. A few studies have also highlighted the involvement of diffuse SC CST damage in motor disabilities. In particular, magnetization transfer imaging metrics in the lateral column of the SC have been found to be correlated with ankle flexion strength $^{11}$, and diffusion imaging metrics with scores on the Expanded Disability Status Scale (EDSS), 9-Hole Peg Test (9HPT) and Timed 25-Foot Walk (T25FW) ${ }^{12}$.

In the present study, we took advantage of advances in SC MRI acquisition and post-processing to assess CST structural integrity in both the cortex and the cervical SC, and examine their relative associations with motor function in a population of patients with early relapsing-remitting MS (RRMS). Structural integrity was assessed using T2 lesion delineations and DTI quantitative measurements in the brain and cervical SC. In addition to standard clinical scores, which are usually slightly impacted at this stage of the disease ${ }^{13}$, we also assessed upper-limb motor functions by electrophysiology in a subset of patients. More specifically, we recorded the central motor conduction time $(\mathrm{CMCT})$ using transcranial magnetic stimulation, whose increase suggests demyelination ${ }^{14}$ or loss of rapidly 
conducting corticospinal fibres, as well as the triple stimulation technique (TST) amplitude ratio, whose decrease suggests central conduction block or axonal loss ${ }^{15,16}$.

\section{Methods}

\section{Participants}

We included 44 patients with early RRMS in this single-center study. All patients underwent an MRI evaluation, and 24 also underwent an electrophysiological evaluation (on a voluntary basis). They were part of a multicenter longitudinal study (EMISEP; ClinicalTrials ID: NCT02117375) approved by the relevant institutional review board. Written informed consent was obtained from all participants. The main inclusion criteria were 1) age 18-45 years, 2) RRMS diagnosis according to 2010 criteria $^{17}<48$ months, 3) initial MRI severity > 9 T2 lesions on brain MRI and/or initial myelitis documented on spinal cord MRI, and 4) no relapse and no corticosteroids in the month before inclusion. Healthy controls were also included for brain $(n=16)$ and spinal cord MRI $(n=19)$ assessment. The demographic characteristics of patients and controls are summarized in Supplementary Table 1.

\section{Study design}

The study design is described below and summarized in Figure 1.

\section{MRI acquisitions}

Imaging was performed using a 3-tesla MRI scanner (MAGNETOM Verio (VB17), Siemens). Details of acquisition parameters are given in Supplemental Material. Briefly: 1) for SC lesion identification, axial T2*w and sagittal T2 TSE from $\mathrm{C} 1$ to $\mathrm{C} 7$; 2) for SC diffusion measurement, diffusion-weighted EPI sequence (30 directions); 3) for brain lesion identification, axial T2w, axial PD, and 3D FLAIR; and 4) for brain CST identification and diffusion measurements, diffusion-weighted EPI sequence (30 directions) and 3DT1 MPRAGE. 


\section{MRI processing}

Processing was performed using the Spinal Cord Toolbox (SCT Version 3.0) ${ }^{18}$ and the Anima toolbox ${ }^{19}$. Details of image analysis are given in Supplemental Material and are summarized below for the patients' scans. The same steps were applied to the controls' scans, except for those concerning lesion identification and alignment.

Spinal cord MRI processing:

- Lesion volume fractions: First, two neurologists (RC, AK) manually delineated cervical cord lesions on the axial $\mathrm{T} 2 *_{\mathrm{W}}$ images, using sagittal $\mathrm{T} 2 \mathrm{w}$ images to help identify the lesions. Second, the SC was segmented and the vertebrae labelled on the $\mathrm{T} 2 * \mathrm{w}$ images. Third, the left and right lateral and ventral components of the CST were extracted using the MNI-Poly-AMU template (Fig. 2). Fourth, the lesion volume fraction was computed as (lesion volume in region of interest) / (ROI volume), with ROIs in the cervical cord defined as right CST, left CST, whole CST, and whole cord. CST sides were named according to their functional lateralization (e.g., the right CST related to motor function on the right side of the body). Level C7 (bottom of the acquisition slab) was removed from this analysis, owing to the difficulty of precisely aligning them on the template.

- Scalar diffusion parameters: First, we corrected the diffusion images for motion and distortion. Second, we applied cord segmentation, level labelling and ROI extraction to the mean diffusion B0 images to locate the left and right lateral CST components in the diffusion acquisition frame. Because of the low resolution of our DTI data, ventral CST components were not extracted, to avoid a detrimental partial volume effect. Third, we extracted the fractional anisotropy (FA), radial diffusivity (RD) and axial diffusivity (AD) maps. Finally, for each participant, the mean values of diffusion parameters for the CST, spine and lesions were extracted for the C2-C4 ROI. We selected this ROI because we judged it to be the least prone to strong geometric distortion and variability in terms of DTI parameters in our control group.

Brain MRI processing:

- Lesion volume fractions: First, two neurologists (RC, AK) manually performed lesion delineation on the 3D-FLAIR images, using T2w and PD images to help lesion identification. Second, diffusion acquisitions were corrected for motion and distortion. Third, lesion masks were rigidly aligned to the diffusion 
acquisitions. Fourth, the WM mask was extracted. Fifth, brain portions of the left and right CSTs were identified after masking out WM lesions, using probabilistic tractography and a set of filtering ROIs (Fig. 3). Finally, for each patient, we computed the lesion volume fractions in the right CST, left CST, whole CST, and whole brain. Lesion fractions were also computed on similar ROIs combining lesion volumes from both the brain and SC.

- Scalar diffusion parameters: The FA, RD and AD parameters were then extracted from the diffusion acquisitions. Finally, for each participant, each of these DTI parameters was averaged on the brain CST, WM, normal-appearing WM, and lesions.

\section{Electrophysiological acquisitions}

The electrophysiological acquisition protocol is fully described in Supplemental Material. Briefly, motor evoked potentials (MEPs), TST amplitude ratio and area measurements were performed on the first dorsal interosseous muscle on each side, using surface electrodes and standard protocols ${ }^{20,21}$. Values $>8 \mathrm{~ms}$ for the CMCT, $<33 \%$ for the MEP ratio, $<93 \%$ for the TST ratio, and $<92 \%$ for the TST area were considered as abnormal ${ }^{15,20}$.

\section{Clinical data}

The clinical assessment included the 1) EDSS and pyramidal EDSS, 2) 9HPT, 3) T25FW, 4) 6-minute walking test (6MWT), and 5) MS walking scale (MSW12).

\section{Statistical analysis}

Statistical analysis was performed in $\mathrm{R}$ (Version 3.4.4) ${ }^{22}$. We used a 0.05 testwise significance level (no correction for multiple comparisons).

Differences in mean DTI metrics between patients and controls for the different ROIs and diffusion parameters and differences in mean electrophysiological scores between sides with and without pyramidal signs were tested by computing the $p$ value associated with the equality of means using Welch's two-sample $t$ test.

Correlations between lesion volume fractions in the brain and cord were assessed using the Pearson correlation coefficient. The associated $p$ values for $r=0$ are also given. 
Correlations between characteristics of CST lesion fractions and electrophysiological scores were calculated using the Spearman correlation coefficient in two different ways. First, we computed the correlations between lesion fractions in the CST (brain, cord and brain + cord) and the quantities from the matching side. Second, to assess the specificity of the lateralization, we also computed correlations between overall nonlateralized variables (whole brain, whole cord, whole central nervous system (CNS) when appropriate) and mean electrophysiological scores. The associated $p$ values for $r=0$ are also given.

Correlations between MRI metrics, electrophysiology and clinical scores were assessed using the Spearman correlation coefficient. The associated $p$ values for $r=0$ are also given. 


\section{Results}

\section{Clinical characteristics}

We included 44 patients with RRMS. Their clinical characteristics are summarized in Table 1. Two of these patients had a motor deficit, and 17 had an isolated pyramidal syndrome with no motor deficit.

\section{MRI characteristics}

\section{Lesion volume fractions}

One patient was excluded from this analysis because motion artifacts on the spinal cord $\mathrm{T} 2 * \mathrm{~W}$ images prevented precise delineation of the lesions. The mean lesion number was 2.5 in the SC (range: 0-8; 6 patients had no spinal cord lesion) and 30 in the brain (range: 2-71). The mean lesion fraction was $5.64 \%(S D=10.61)$ in the whole cervical SC and $0.26 \%(S D=0.21)$ in the whole brain. Regarding the CST, mean absolute T2 lesion volumes were $52.5 \mathrm{~mm}^{3}$ in the SC and $121.9 \mathrm{~mm}^{3}$ in the brain. After normalizing for region volume, mean lesion fraction was $5.18 \%(S D=10.05)$ in the SC CST and $0.88 \%(S D=1.45)$ in the brain CST. Two patients had no CST lesions. Detailed results are provided in Table 2. Lesion volume fractions in the whole SC and the SC CST were strongly correlated $(r=0.96,95 \%$ CI $[0.93,0.98], p<\mathrm{e}-16)$. We also observed a similar, albeit less pronounced, correlation in the brain $(r=0.49,95 \%$ CI $[0.22,0.69], p=0.001)$. By contrast, we did not find any evidence of a correlation between the lesion volume fractions in the brain and SC $(r=0.06,95 \% \mathrm{CI}[-0.24,0.36], p=0.68)$.

\section{DTI metrics in patients and controls}

Table 3 gives the results of FA, RD and $\mathrm{AD}$ metrics for the $\mathrm{SC}$ and brain for patients and controls. In the whole cervical cord, we found evidence of differences between controls and patients for FA and RD, even after excluding lesions. When we focused on the CST, evidence of significant differences between the two groups vanished. In the whole brain and brain CST, we found no evidence of differences between controls' and patients' diffusion parameters. Moreover, we do not observe evidences of correlations between lesion fraction in the spinal cord and values of DTI metric in the spinal cord (Supplementary Table 2).

\section{Electrophysiological scores}


We collected electrophysiological data from 44 sides ( 21 right side and 23 left side). Four patients declined the electrophysiological assessment on one side, and one patient was excluded from the TST analysis because of repolarization abnormalities. The electrophysiological assessments are detailed in Supplementary Table 3. Twelve of the 24 patients (19 of the 44 sides) had at least one abnormal value (7/44 CMCT, 9/42 MEP ratio, and 15/42 TST

ratio). Sides associated with pyramidal signs experienced lower mean TST ratio scores than sides without pyramidal signs $(74.44, \mathrm{SD}=24.40$ versus $95.34, \mathrm{SD}=11.13, \mathrm{p}=4 \mathrm{e}-04$, Table 4$)$.

\section{Associations between MRI metrics and clinical scores}

\section{Lesion volume fractions and clinical scores}

Detailed correlations are provided in Table 5. EDSS was correlated with the lesion fraction of the whole SC $(r=$ $0.41, p=0.007)$. Pyramidal EDSS was positively correlated with the lesion fractions of the SC CST $(r=0.39, p=$ $0.01)$, whole SC $(r=0.34, p=0.02)$ and brain + spine CST $(r=0.41, p=0.007)$.

\section{DTI parameters and clinical scores}

We did not observe significant correlations between diffusion parameters and clinical data. (Supplementary Table 4).

\section{Lateralized associations between MRI metrics and electrophysiology}

Detailed correlations are provided in Table 6. CMCT was correlated with lesion fraction in the spine CST ( $\mathrm{r}=0.33$, $\mathrm{p}=0.03)$ and CNS $(r=0.49, p=0.04)$. TST amplitude ratio and TST area were correlated with the lesion fraction in the brain CST $(r=-0.34, \mathrm{p}=0.03$ and $r=-0.40, p=0.01)$. Both these electrophysiological parameters were also associated with the lesion fraction in the brain + spine CST $(r=-0.39, p=0.01$ and $r=-0.48, p=0.002)$. Detailed correlations between clinical metrics and electrophysiology are provided in Supplementary Table 5. 


\section{Discussion}

The main contribution of our study was to perform a description of CST damage from the primary motor cortex to the low cervical cord, quantifying both focal lesion load and diffuse tissue damage, as well as in the brain and SC. Moreover, we precisely assessed the impact of CST structural damage on patients' motor functions, by combining clinical tests and electrophysiology. The main conclusions of this work are threefold:

First, CST focal lesions were frequent, concerning 42 of the 44 patients with early RRMS. This result is in line with the literature ${ }^{5,23}$, although previous studies only quantified brain CST lesion load. More importantly, we found that the lesion load was not homogeneously distributed along the CST. The T2 absolute lesion volume was about twice as high in the brain portion of the CST as in its SC portion. However, the volume of the cervical cord CST was also much lower than the volume of the brain CST. Thus, after normalization for each ROI volume, the focal damage proved to be far more pronounced in the SC portion of the CST than in the brain portion, indicating that the SC portion of the CST is vulnerable to lesions. Moreover, the lesion fractions in the SC CSTs were more closely correlated with pyramidal EDSS scores and CMCT than those in the brain CST, or even the brain + spine CST, emphasizing the highly functional aspect of the SC. We also found a close correlation between the SC CST lesion fraction and the whole cord lesion fraction. Owing to the small size of the spinal cord, a focal lesion is highly likely to impact the CST. Consequently, there was very little added value in specifically studying the CST lesion fraction compared with the whole SC lesion fraction in our study.

Second, we found evidence of differences in SC diffusion parameters between patients and controls, illustrating the presence of measurable focal as well as diffuse damage in the SC at the beginning of the disease. These results confirm a recent study where similar conclusions were reached using magnetization transfer ratio imaging ${ }^{24}$. By contrast, we did not observe any significant differences in brain WM diffusion parameters between patients and controls. Like the lack of correlation between the SC and brain lesion fractions, this result illustrates the value of not limiting damage analysis to the brain portion of the CNS to characterize patients' pathophysiological state. Previous studies $^{5,6,27}$ have reported evidence of patient-to-control differences on various diffusion parameters in brain WM, but these involved patients with more advanced disease (mean EDSS = 4, 2.8 and 1.5, compared with 0.8 in our population). When we specifically focused on the SC portion of the CST, we did not observe any significant differences in diffusion parameters between patients and controls. This result can probably partly be explained by the 
low resolution of our DTI spinal cord imaging $\left(2 * 2 * 2 \mathrm{~mm}^{3}\right)$ resulting in a notable partial volume effect and more variable DTI measurements.

Third, despite the high occurrence of CST structural damage in our cohort, only 50\% of patients had electrophysiologically measurable functional consequences, $38 \%$ had a pyramidal syndrome, and $5 \%$ had a motor deficit. This can probably be explained by the varying degrees of demyelination and axonal loss in focal MS lesions reported in anatomopathological studies ${ }^{25}$, leading to differing consequences in terms of conduction time or conduction block. In the present study, we used both $\mathrm{CMCT}^{14}$, which reflects demyelination or loss of rapidly conducting corticospinal fibres, and the TST amplitude ratio, which reflects a conduction failure resulting from either central conduction block or axonal $\operatorname{loss}^{15,16}$. Accordingly, the TST ratio abnormalities were associated with pyramidal signs, whereas no association was found with the CMCT. These results were in line with a previous study ${ }^{13}$. However, the correlations between lesion fractions in the CST and electrophysiological parameters are more difficult to interpret, as lesion fraction does not specifically reflect demyelination or axonal loss. It would be worthwhile carrying out a precise quantification of lesion severity using quantitative MRI techniques such as submillimetric axial MT imaging in future studies, in order to better explain the link between MRI and electrophysiological parameters.

\section{Limitations}

First, our analysis did not include the thoracic segment of the SC. To date, the acquisition and postprocessing of thoracic SC images has proved more challenging than for the cervical portion ${ }^{7}$. Second, CST delineation is only an approximation, even using state-of-the-art techniques such as tractography for the brain and an atlas for SC ${ }^{26}$. Third, our sample consisted of 43 patients with early RRMS, and 16 controls for the brain and 19 for the SC acquisitions. This moderate sample size was nonetheless sufficient to highlight the stronger involvement of SC lesions in CST damage and motor function abnormalities, compared with brain lesions. Fourth, we only included patients with early RRMS in our study. Consequently, only two patients had a motor deficit, thus preventing us from evaluating the link between CST lesion load and clear motor disability. While this was beyond the scope of the present study, it would be worthwhile including patients with different MS phenotypes and more advanced disease in future studies. Moreover, our population consisted of patients who met criteria for disease severity (> 9 brain lesions and/or myelitis). Thus, we cannot exclude the possibility that these inclusion criteria introduced a bias toward an overrepresentation of focal SC lesions in our cohort. It will be important to reproduce these results in other cohorts. 


\section{Conclusions and perspectives}

Our study described both the structural and functional involvement of the CST in the brain and cervical SC. Our results highlight the high frequency of focal CST damage even in the first few years of RRMS, as well as the major contribution of SC lesions to CST damage and motor function abnormalities. The link between early CST lesion volume fraction and subsequent motor disability will be evaluated in an ongoing longitudinal study. 


\section{References}

1. Lublin FD, Reingold SC, Cohen JA, et al. Defining the clinical course of multiple sclerosis: the 2013 revisions. Neurology 2014;83(3):278-286.

2. Wilson M, Tench C, Morgan P and Blumhardt L. Pyramidal tract mapping by diffusion tensor magnetic resonance imaging in multiple sclerosis: improving correlations with disability. J Neurol Neurosurg Psychiatry 2003;74:203-207.

3. Fritz N, Keller J, Calabresi P and Zackowski K. Quantitative measures of walking and strength provide insight into brain corticospinal tract pathology in multiple sclerosis. NeuroImage Clin 2017;14:490-498.

4. Tovar-Moll F, Evangelou L, Chiu A, et al. Diffuse and focal corticospinal tract disease and its impact on patient disability in Multiple sclerosis. J Neuroimaging 2015;25:200-206.

5. Daams M, Steenwijk M, Wattjes M, et al. Unraveling the neuro-imaging predictors for motor dysfunction in longstanding multiple sclerosis. Neurology 2015;85:1-8.

6. Lin F, Yu C, Jiang T, et al. Diffusion tensor tractography-based group mapping of the pyramidal tract in relapsing remitting Multiple Sclerosis patients. Am J Neuroradiol 2007;28: 278-85.

7. Martin AR, Aleksanderek I, Cohen-Adad J, et al. Translating state-of-the-art spinal cord MRI techniques to clinical use: a systematic review of clinical studies utilizing DTI, MT, MWF, MRS, and fMRI. NeuroImage Clin 2016;10:192-238.

8. Kearney H, Altmann DR, Samson RS, et al. Cervical cord lesion load is associated with disability independently from atrophy in MS. Neurology 2015;84(4):367-73.

9. Brownlee WJ, Altmann DR, Alves Da Mota P, et al. Association of asymptomatic spinal cord lesions and atrophy with disability 5 years after a clinically isolated syndrome. Mult Scler. 2017 Apr;23(5):665-674.

10. Arrambide G, Rovira A, Sastre-Garriga J, et al. Spinal cord lesions: a modest contributor to diagnosis in clinically isolated syndromes but a relevant prognostic factor. Mult Scler 2017;23(5):665-674.

11. Zackowski K, Smith S, Calabresi P, et al Sensorimotor dysfunction in multiple sclerosis and column-specific magnetization transfer-imaging abnormalities in the spinal cord. Brain 2009;132(Pt 5):1200-9.

12. Naismith RT, Xu J, Klawiter EC, et al. Spinal cord tract diffusion tensor imaging reveals disability substrate in demyelinating disease. Neurology 2013;80(24):2201-9.

13. Rico A, Audoin B, Franques J, et al. Motor evoked potentials in clinically isolated syndrome suggestive of 
multiple sclerosis. Mult.Scler 2009;15:355-362.

14. Kidd D, Thompson PD, Day BL, et al. Central motor conduction time in progressive multiple sclerosis. Correlations with MRI and disease activity. Brain 1998;121: 1109-1116.

15. Magistris MR, Rosler KM, Truffert A, et al. A clinical study of motor evoked potentials using a triple stimulation technique. Brain 1999;122: 265-279.

16. Buhler R, Magistris MR, Truffert A, et al. The triple stimulation technique to study central motor conduction to the lower limbs. Clin Neurophysiol 2001;112:938-949.

17. Polman C, Reingold SC, Banwell B, et al. Diagnostic criteria for multiple sclerosis: 2010 revisions to the McDonald criteria. Ann Neurol 2011; 69:292-302.

18. De Leener B, Lévy S, Dupont SM, et al. SCT: Spinal Cord Toolbox, an open-source software for processing spinal cord MRI data. Neuroimage 2017;145:27-43.

19. Commowick O, Wiest-Daessle N and Prima S. Block-matching strategies for rigid registration of multimodal medical images [Internet]. In: 2012 9th IEEE International Symposium on Biomedical Imaging (ISBI). 2012. Available from: http://dx.doi.org/10.1109/isbi.2012.6235644

20. Rossini P, Burke D, Chen R, et al. Non-invasive electrical and magnetic stimulation of the brain, spinal cord, roots and peripheral nerves: Basic principles and procedures for routine clinical and research application: An updated report from an I.F.C.N. Committee. Clinical Neurophysiology 2015;126(6):1071-1107.

21. Magistris MR, Rösler KM. Chapter 3 The triple stimulation technique to study corticospinal conduction. Supplements to Clinical Neurophysiology 2003 (Vol. 56).

22. https://www.r-project.org

23. Pagani E, Filippi M, Rocca MA and Horsfield MA. A method for obtaining tract-specific diffusion tensor MRI measurements in the presence of disease: application to patients with clinically isolated syndromes suggestive of multiple sclerosis. Neuroimage 2005;26(1):258-65.

24. Combès B, Kerbrat A, Ferré JC, et al. Focal and diffuse cervical spinal cord damage in patients with early relapsing-remitting MS: a multicentre magnetisation transfer ratio study. Mult Scler 2018 Jun 1:1352458518781999. doi: $10.1177 / 1352458518781999$.

25. Frischer J, Weigand S, Guo Y, et al. Clinical and pathological insights into the dynamic nature of the white matter multiple sclerosis plaque. Ann Neurol 2015;78(5):710-721.

26. Lévy S, Benhamou M, Naaman C, et al. White matter atlas of the human spinal cord with estimation of partial volume effect. Neuroimage 2015;119:262-271. 
27. Bommarito G, Bellini A, Pardini M, et al. Composite MRI measures and short-term disability in patients with clinically isolated syndrome suggestive of MS. Mult Scler 2017; 5:623-631. 


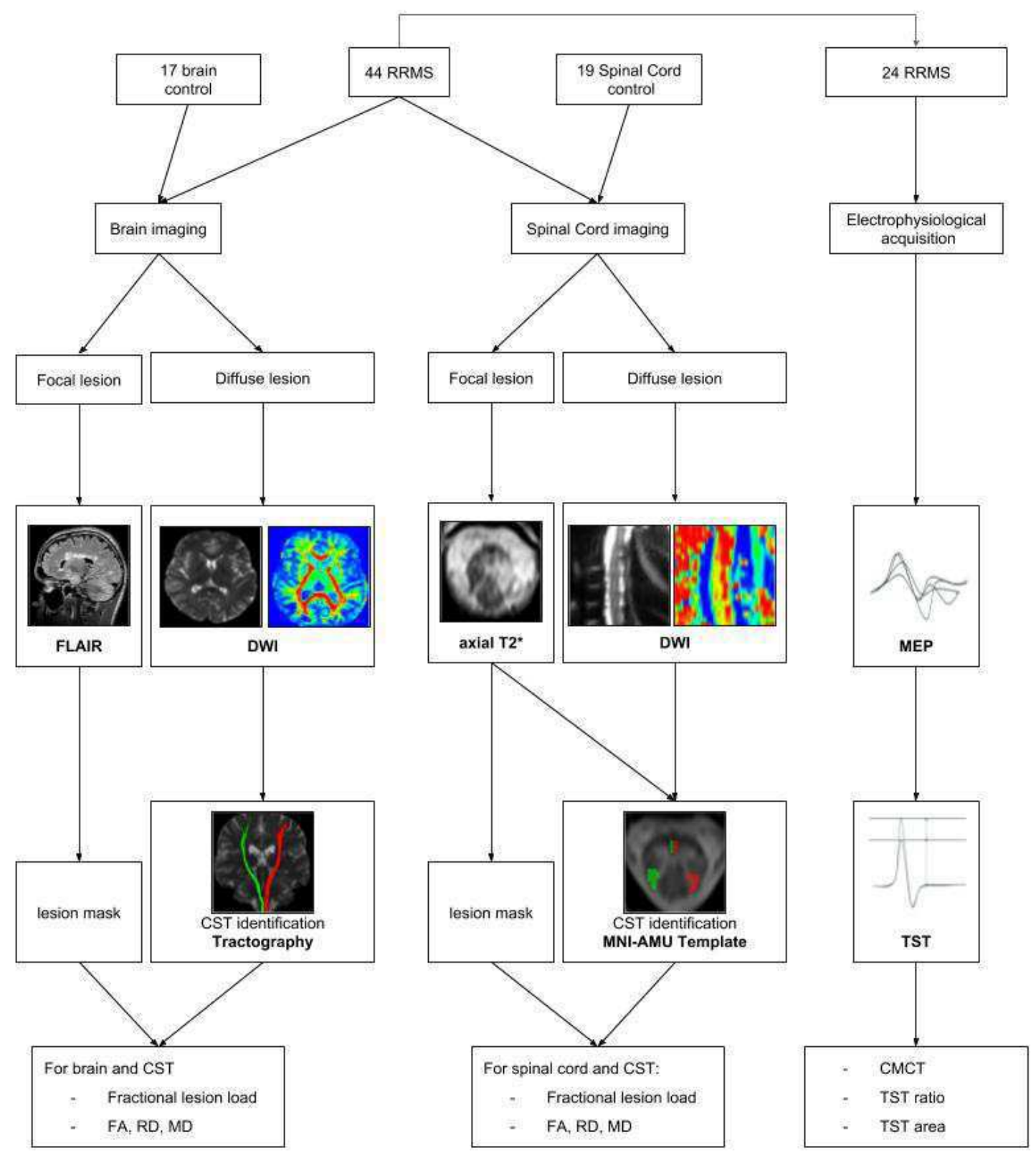

\section{Figure 1: Study design.}

RRMS = relapsing-remitting multiple sclerosis; DWI $=$ diffusion-weighted imaging; CST $=$ corticospinal tract; MEP $=$ motor evoked potential; TST $=$ triple stimulation technique CMCT $=$ central motor conduction time; $\mathrm{FA}=$ fractional anisotropy; $\mathrm{RD}=$ radial diffusivity; $\mathrm{AD}=$ axial diffusivity. 


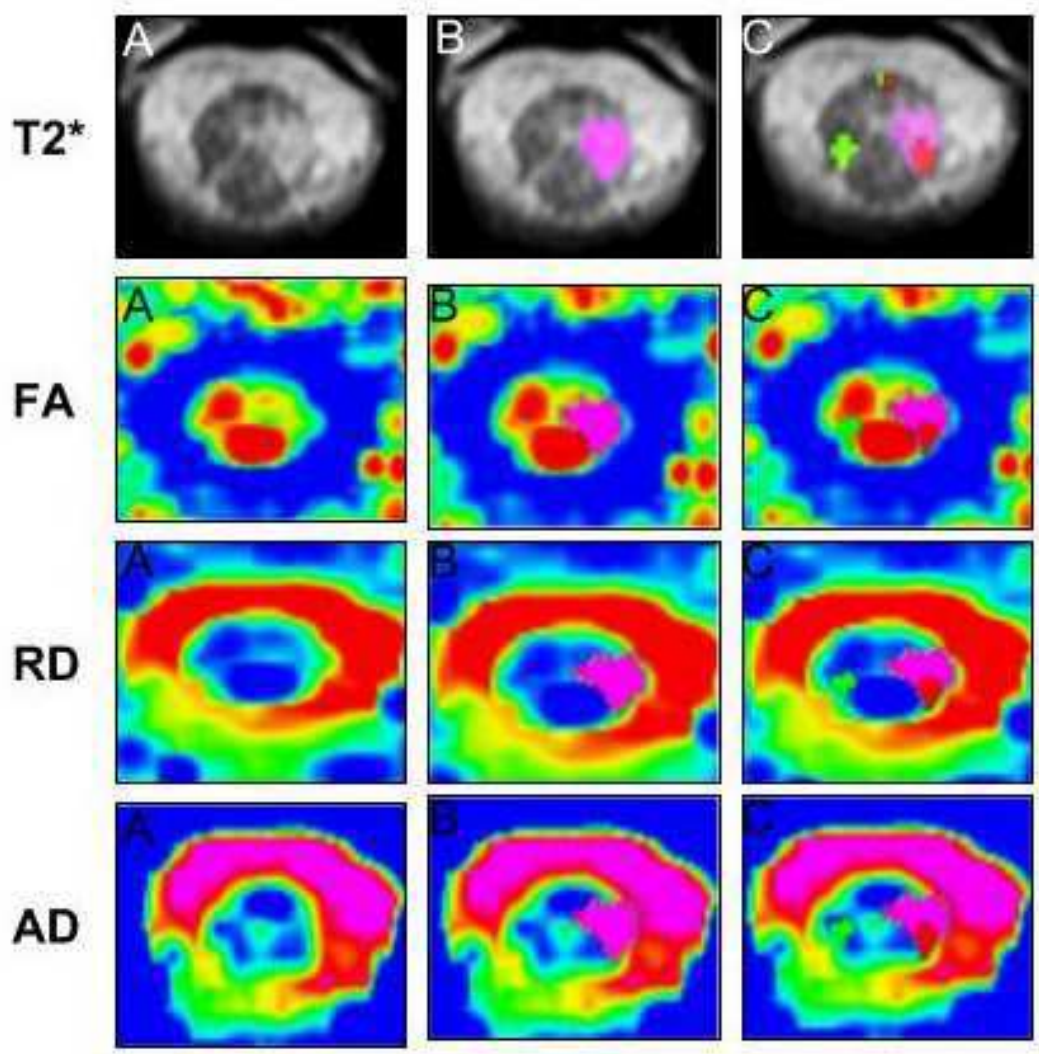

Figure 2: Example of spinal cord MRI in a patient with RMMS.

First row: axial T2*. Other rows: DTI parameter maps. A: native image; B: segmented lesion in pink; C: masks of corticospinal tract crossing the lesion (left CST in red, right CST in green). FA = fractional anisotropy; RD = radial diffusivity; $\mathrm{AD}=$ axial diffusivity. 


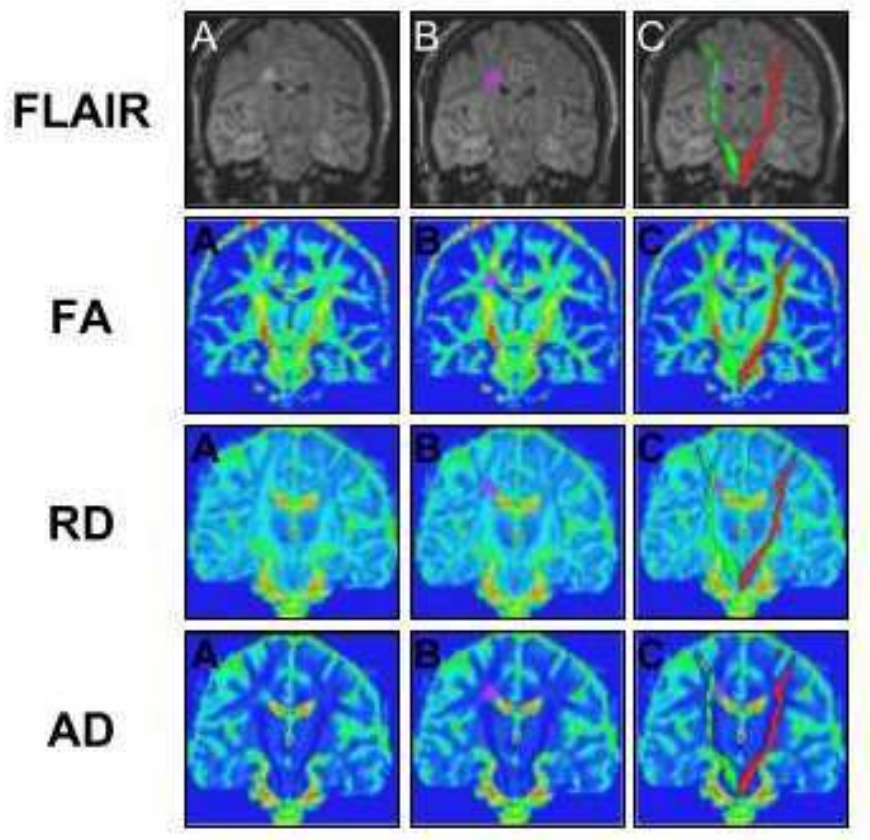

Figure 3: Example of brain MRI in patient with RRMS.

First row: FLAIR acquisition registered on b0 image. Other rows: parametric maps. $\mathrm{A}=$ native images; $\mathrm{B}=$ segmented lesion in pink; $\mathrm{C}=$ masks of corticospinal tract crossing the lesion (left CST in red, right CST in green); $\mathrm{FA}=$ fractional anisotropy $\mathrm{RD}=$ radial diffusivity $\mathrm{AD}=$ axial diffusivity. 


\begin{tabular}{|c|c|c|}
\hline \multicolumn{3}{|c|}{ Clinical characteristics $(N=44)$} \\
\hline Age (years) & Mean $\pm S D$ & $30.7 \pm 6.4$ \\
\hline Sex & $(\mathrm{F} / \mathrm{M})$ & $28 / 16$ \\
\hline $\begin{array}{c}\text { Disease duration } \\
\text { (months) }\end{array}$ & Mean $\pm S D$ & $21.1 \pm 11.40$ \\
\hline EDSS & median (range) & $1(0-3)$ \\
\hline Pyramidal EDSS & median (range) & $0(0-2)$ \\
\hline 9-HPT right (s) & mean $\pm S D$ (range) & $19.1 \pm 4.4(13.9-40.6)$ \\
\hline 9-HPT left (s) & mean $\pm S D$ (range) & $19.7 \pm 5.7(14.5-54.1)$ \\
\hline 6MWT (m) & mean $\pm S D$ (range) & $540 \pm 95(324-822)$ \\
\hline T25FW (min) & mean $\pm S D$ (range) & $4.9 \pm 0.8(3.8-7.8)$ \\
\hline MSW12 & mean $\pm S D$ (range) & $17.2 \pm 10.7(12-54)$ \\
\hline Right pyramidal signs & (yes/no) & $8 / 36$ \\
\hline Left pyramidal signs & (yes/no) & $9 / 35$ \\
\hline Disease modifying drugs & \multicolumn{2}{|c|}{$\begin{array}{l}\text { Fingolimod n=9; Interferon n=10; Glatiramer acetate } n=11 \text {; Teriflunomid } n=6 \text {; Dimethyl } \\
\text { fumarate } n=3 \text {, Other } n=4 \text { (Rituximab, Natalizumab, Mycophenolic acid, Alemtezumab), no } \\
\qquad \text { DMD n=1. }\end{array}$} \\
\hline
\end{tabular}

Table 1: Clinical characteristics of patients.

EDSS = Expanded Disability Status Scale; T25FW = Timed 25-Foot Walk Test; 9HPT = 9-Hole Peg Test; 6MWT = 6-Minute Walking Test; MSW12 = MS Walking Scale. 


\begin{tabular}{|c|c|c|c|c|c|}
\hline & & \multicolumn{2}{|c|}{ WHOLE } & \multicolumn{2}{|c|}{ CST } \\
\hline & & $\begin{array}{l}\text { Lesion volume in } \\
\qquad \mathrm{ROI}\left(\mathrm{mm}^{3}\right)\end{array}$ & $\begin{array}{l}\text { Percentage of } \\
\text { lesions in ROI }\end{array}$ & $\begin{array}{l}\text { Lesion volume in } \\
\text { ROI }\left(\mathrm{mm}^{3}\right)\end{array}$ & $\begin{array}{l}\text { Percentage of } \\
\text { lesions in ROI }\end{array}$ \\
\hline Spinal cord & $\begin{array}{l}\text { Mean } \pm S D \\
(\min , \max )\end{array}$ & $\begin{array}{l}425.20 \pm 790.48 \\
(0.00,4160.23)\end{array}$ & $\begin{array}{l}5.64 \pm 10.61 \\
(0.00,57.00)\end{array}$ & $\begin{array}{l}52.54 \pm 99.67 \\
(0.00,568.16)\end{array}$ & $\begin{array}{l}5.18 \pm 10.45 \\
(0.00,62.44)\end{array}$ \\
\hline Brain & $\begin{array}{l}\text { Mean } \pm S D \\
(\min , \max )\end{array}$ & $\begin{array}{l}3668.84 \pm 3,292.29 \\
(187.45,16916.51)\end{array}$ & $\begin{array}{l}0.26 \pm 0.21 \\
(0.01,1.00)\end{array}$ & $\begin{array}{c}121.86 \pm 214.08 \\
(0.00,976.00)\end{array}$ & $\begin{array}{l}0.88 \pm 1.45 \\
(0.00,5.44)\end{array}$ \\
\hline $\begin{array}{l}\text { Spinal cord } \\
\text { + Brain }\end{array}$ & $\begin{array}{l}\text { Mean } \pm S D \\
(\min , \max )\end{array}$ & $\begin{array}{l}4094.04 \pm 3435.63 \\
(187.45,17080.47)\end{array}$ & $\begin{array}{l}0.28 \pm 0.23 \\
(0.01,1.00)\end{array}$ & $\begin{array}{l}174.40 \pm 241.30 \\
(0.00,1207.26)\end{array}$ & $\begin{array}{l}1.23 \pm 1.71 \\
(0.00,7.60)\end{array}$ \\
\hline
\end{tabular}

Table 2: Brain, spinal cord and corticospinal tract lesion volume.

White column: Mean, standard deviation and range for lesion volume in each ROI (in mm3). Gray column: Mean, standard deviation and range for lesion volume fraction in each ROI (i.e., percentage of lesions in ROI). 


\begin{tabular}{|c|c|c|c|}
\hline & $\begin{array}{c}\text { Controls } \\
\text { (Spinal cord: } n=18 \text {, } \\
\text { Brain } n=16 \text { ) }\end{array}$ & $\begin{array}{l}\text { Patients } \\
(n=43)\end{array}$ & $\begin{array}{c}\text { p value } \\
\text { for no control-to-patient } \\
\text { difference }\end{array}$ \\
\hline \multicolumn{4}{|c|}{ Spinal cord } \\
\hline \multicolumn{4}{|l|}{ FA } \\
\hline whole spinal cord & $0.719(0.054)$ & 0.664 (0.079) & 0.009 \\
\hline NASC & - & $0.661(0.081)$ & 0.002 \\
\hline CST & $0.746(0.078)$ & $0.712(0.093)$ & 0.180 \\
\hline lesion & - & $0.655(0.115)$ & - \\
\hline \multicolumn{4}{|l|}{$\mathrm{RD}(x \mathrm{1000})$} \\
\hline whole spinal cord & $0.406(0.076)$ & $0.483(0.119)$ & 0.014 \\
\hline NASC & - & $0.492(0.127)$ & 0.002 \\
\hline CST & $0.366(0.114)$ & $0.408(0.138)$ & 0.258 \\
\hline lesion & - & $0.473(0.149)$ & - \\
\hline \multicolumn{4}{|l|}{$A D(x 100)$} \\
\hline whole spinal cord & $0.158(0.014)$ & $0.158(0.014)$ & 0.946 \\
\hline NASC & - & $0.159(0.014)$ & 0.760 \\
\hline CST & $0.159(0.014)$ & $0.158(0.016)$ & 0.800 \\
\hline lesion & - & $0.156(0.018)$ & - \\
\hline
\end{tabular}




\begin{tabular}{|c|c|c|c|}
\hline \multicolumn{4}{|c|}{ Brain } \\
\hline \multicolumn{4}{|l|}{ FA } \\
\hline WM & $0.346(0.025)$ & $0.341(0.020)$ & 0.451 \\
\hline NAWM & $0.346(0.025)$ & $0.342(0.020)$ & 0.518 \\
\hline CST & $0.480(0.025)$ & $0.469(0.024)$ & 0.139 \\
\hline lesion & - & $0.311(0.038)$ & - \\
\hline \multicolumn{4}{|c|}{ RD $(x 1000)$} \\
\hline WM & $0.610(0.045)$ & $0.613(0.046)$ & 0.791 \\
\hline NAWM & $0.610(0.045)$ & $0.611(0.046)$ & 0.914 \\
\hline CST & $0.548(0.048)$ & $0.556(0.039)$ & 0.533 \\
\hline lesion & - & $0.870(0.103)$ & - \\
\hline \multicolumn{4}{|c|}{$A D(x 100)$} \\
\hline WM & $0.105(0.003)$ & $0.105(0.004)$ & 0.623 \\
\hline NAWM & $0.105(0.003)$ & $0.104(0.004)$ & 0.427 \\
\hline CST & $0.120(0.005)$ & $0.120(0.005)$ & 0.679 \\
\hline lesion & - & $0.139(0.014)$ & - \\
\hline
\end{tabular}

Table 3: Mean (standard deviation) diffusion parameter values for patients and controls and $p$ values associated with no differences between patients and controls.

$\mathrm{FA}=$ fractional anisotropy $\mathrm{RD}=$ radial diffusivity; $\mathrm{AD}=$ axial diffusivity; $\mathrm{NA}=$ normal-appearing . 


\begin{tabular}{|c|c|c|c|}
\hline & $\begin{array}{l}\text { Sides without } \\
\text { pyramidal signs } \\
\qquad(n=31)\end{array}$ & $\begin{array}{l}\text { Sides with pyramidal } \\
\text { signs } \\
(n=11)\end{array}$ & $\begin{array}{c}\text { p-value for no } \\
\text { difference between the } \\
\text { two groups }\end{array}$ \\
\hline СMCT & $6.29(1.44)$ & $7.54(3.32)$ & 0.09 \\
\hline TST ratio & 98.30 (9.32) & $75.46(20.62)$ & $1.3 e-05$ \\
\hline TST area & $95.34(11.13)$ & $74.44(24.40)$ & $4.4 \mathrm{e}-04$ \\
\hline
\end{tabular}

Table 4: Mean (standard deviation) electrophysiological scores for sides without pyramidal signs and with pyramidal signs, as well as the $p$ values associated with no differences between the two groups.

$\mathrm{CMCT}=$ central motor conduction time; $\mathrm{TST}=$ triple stimulation technique. 


\begin{tabular}{|c|c|c|c|c|c|c|c|}
\hline & & EDSS & pyEDSS & MSWS12 & 9HРТ & 6MWT & 25FTW \\
\hline \multirow{2}{*}{ Spinal cord } & CST & $\begin{array}{l}r=0.25 \\
p=0.11\end{array}$ & $\begin{array}{l}r=0.39 \\
p=0.01\end{array}$ & $\begin{array}{l}r=0.10 \\
p=0.52\end{array}$ & $\begin{array}{l}r=0.26 \\
p=0.09\end{array}$ & $\begin{array}{l}r=-0.22 \\
p=0.15\end{array}$ & $\begin{array}{l}r=0.11 \\
p=0.50\end{array}$ \\
\hline & $\begin{array}{l}\text { Whole } \\
\text { spinal cord }\end{array}$ & $\begin{array}{c}r=0.41 \\
p=0.007\end{array}$ & $\begin{array}{l}r=0.34 \\
p=0.02\end{array}$ & $\begin{array}{l}r=0.26 \\
p=0.09\end{array}$ & $\begin{array}{l}r=0.20 \\
p=0.20\end{array}$ & $\begin{array}{l}r=-0.16 \\
p=0.32\end{array}$ & $\begin{array}{l}r=0.16 \\
p=0.32\end{array}$ \\
\hline \multirow{2}{*}{ Brain } & CST & $\begin{array}{l}r=0.08 \\
p=0.62\end{array}$ & $\begin{array}{l}r=0.16 \\
p=0.30\end{array}$ & $\begin{array}{l}r=0.01 \\
p=0.95\end{array}$ & $\begin{array}{l}r=0.18 \\
p=0.26\end{array}$ & $\begin{array}{l}r=-0.05 \\
p=0.72\end{array}$ & $\begin{array}{l}r=-0.06 \\
p=0.72\end{array}$ \\
\hline & $\begin{array}{l}\text { Whole } \\
\text { brain }\end{array}$ & $\begin{array}{c}r=0.004 \\
p=0.98\end{array}$ & $\begin{array}{l}r=0.09 \\
p=0.54\end{array}$ & $\begin{array}{l}r=0.08 \\
p=0.59\end{array}$ & $\begin{array}{l}r=0.08 \\
p=0.57\end{array}$ & $\begin{array}{l}r=0.07 \\
p=0.64\end{array}$ & $\begin{array}{l}r=-0.03 \\
p=0.87\end{array}$ \\
\hline \multirow{2}{*}{$\begin{array}{c}\text { Spinal cord } \\
+ \\
\text { Brain }\end{array}$} & CST & $\begin{array}{l}r=0.24 \\
p=0.12\end{array}$ & $\begin{array}{c}r=0.41 \\
p=0.007\end{array}$ & $\begin{array}{l}r=0.16 \\
p=0.32\end{array}$ & $\begin{array}{l}r=020 \\
p=0.20\end{array}$ & $\begin{array}{l}r=-0.04 \\
p=0.79\end{array}$ & $\begin{array}{l}r=0.04 \\
p=0.79\end{array}$ \\
\hline & Whole & $\begin{array}{l}r=0.10 \\
p=0.50\end{array}$ & $\begin{array}{l}r=0.23 \\
p=0.14\end{array}$ & $\begin{array}{l}r=0.12 \\
p=0.46\end{array}$ & $\begin{array}{l}r=0.12 \\
p=0.43\end{array}$ & $\begin{array}{l}r=-0.01 \\
p=0.93\end{array}$ & $\begin{array}{l}r=-0.01 \\
p=0.93\end{array}$ \\
\hline
\end{tabular}

Table 5: Correlation coefficients and $\boldsymbol{p}$ values between lesion volume fractions and clinical scores

Significant results are indicated in bold. EDSS $=$ Expanded Disability Status Scale; T25FW = Timed 25-Foot Walk Test; 9HPT = 9-Hole Peg Test; 6MWT = 6-Minute Walking Test; MSW12 = MS Walking Scale; AMSQ = Arm Function in MS Questionnaire. 


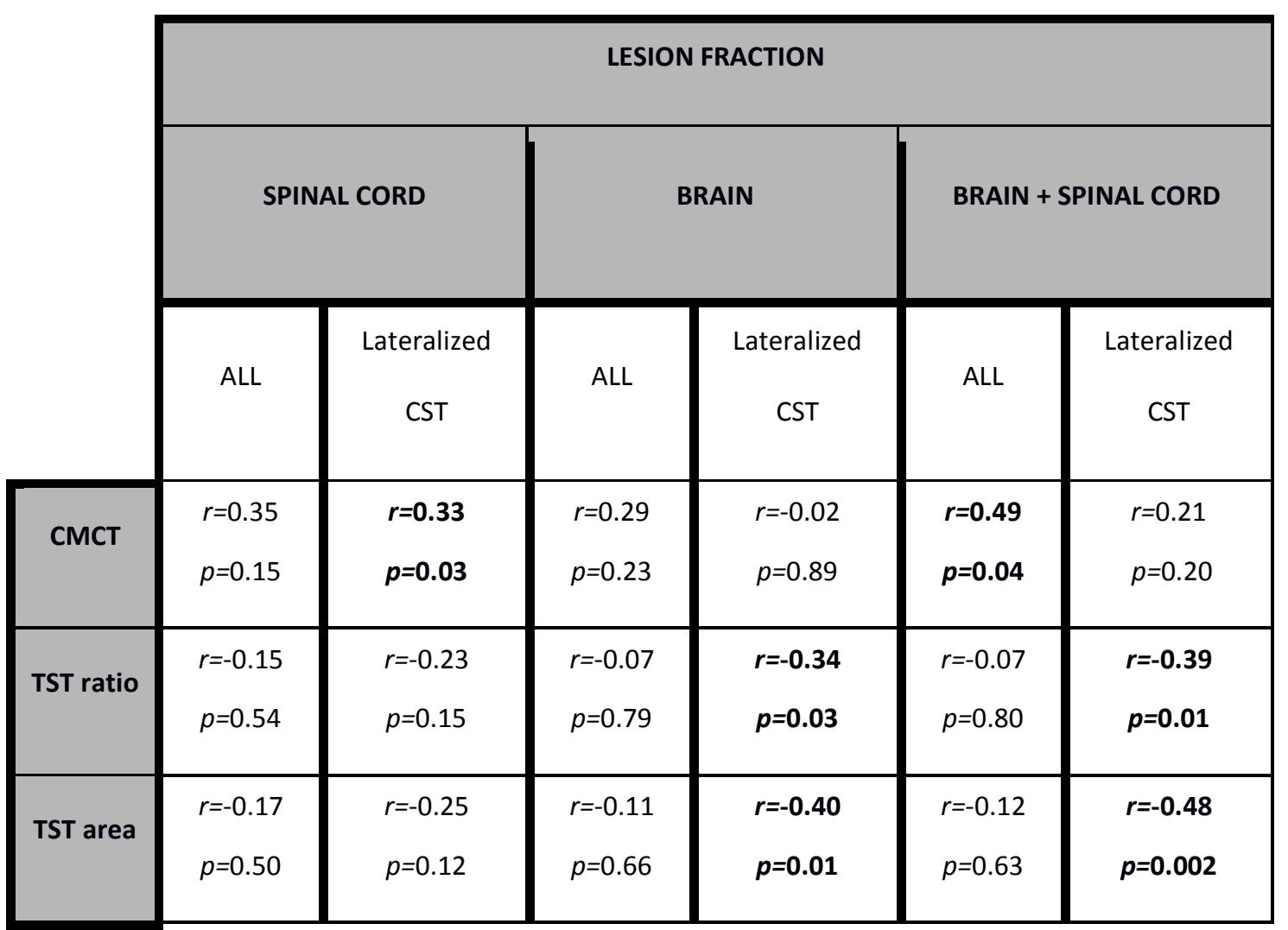

Table 6: Correlations between electrophysiological data and lesion fractions in spinal cord, brain and central nervous system.

Significant values are indicated in bold. Lateralized CST $=$ corresponding functional corticospinal tract. $\mathrm{CMCT}=$ central motor conduction time; TST $=$ triple stimulation technique. 


\begin{tabular}{|c|c|c|c|c|c|}
\hline & & \multicolumn{2}{|c|}{ Patients } & \multirow{2}{*}{$\begin{array}{l}\text { Spinal cord } \\
\text { MRI controls }\end{array}$} & \multirow{2}{*}{$\begin{array}{c}\text { Brain MRI } \\
\text { controls }\end{array}$} \\
\hline & & MRI & Electrophysiology & & \\
\hline Number & & 44 & $24 / 44$ & 19 & 16 \\
\hline Sex F/M & & $28 / 16$ & $13 / 11$ & $11 / 8$ & $11 / 5$ \\
\hline Age (years) & Mean $\pm S D$ & $30.7 \pm 6.4$ & $33.3 \pm 5.9$ & $33.7 \pm 7.8$ & $39.3 \pm 9.1$ \\
\hline
\end{tabular}

Supplementary Table 1: Summary of participants' demographic characteristics. 


\begin{tabular}{|c|c|c|}
\hline \multicolumn{2}{|c|}{ SPINE } & $\begin{array}{c}\text { All spine lesion } \\
\text { fraction }\end{array}$ \\
\hline \multirow{4}{*}{ Mean FA } & lesion & $\begin{array}{c}r=0.068 \\
p=0.694\end{array}$ \\
\cline { 2 - 4 } & all spine & $\begin{array}{c}r=-0.048 \\
p=0.759\end{array}$ \\
\hline \multirow{4}{*}{ Mean RD } & lesion & $\begin{array}{c}r=-0.029 \\
p=0.865\end{array}$ \\
\cline { 2 - 4 } & all spine & $\begin{array}{c}r=0.08 \\
p=0.961\end{array}$ \\
& lesion & $\begin{array}{c}r=-0.016 \\
p=0.924\end{array}$ \\
\cline { 2 - 4 } Mean AD & all spine & $\begin{array}{c}r=-0.120 \\
p=0.445\end{array}$ \\
\cline { 2 - 4 } & &
\end{tabular}

Supplementary Table 2: Correlations between DTI metrics of the spinal cord and lesion fraction of the spinal cord

$\mathrm{FA}=$ fractional anisotropy $\mathrm{RD}=$ radial diffusivity; $\mathrm{AD}=$ axial diffusivity. 


\begin{tabular}{|c|c|c|c|c|}
\hline & & Right & Left & Total \\
\hline СMCT (ms) & $\begin{array}{c}\text { Mean } \pm S D \\
\text { (range) }\end{array}$ & $\begin{array}{c}n=20 \\
6.6 \pm 2.4 \\
(3.3-14.4)\end{array}$ & $\begin{array}{c}n=22 \\
6.7 \pm 1.9 \\
(3.7-12.9)\end{array}$ & $\begin{array}{c}n=42 \\
6.6 \pm 2.1 \\
(3.3-14.4)\end{array}$ \\
\hline TST ratio (\%) & $\begin{array}{c}\text { Mean } \pm S D \\
\text { (range) }\end{array}$ & $\begin{array}{c}n=20 \\
91.1 \pm 15.1 \\
(45.3-110.3)\end{array}$ & $\begin{array}{c}n=22 \\
93.4 \pm 17.9 \\
(33.3-121.3)\end{array}$ & $\begin{array}{c}n=42 \\
92.3 \pm 16.5 \\
(33.3-121.3)\end{array}$ \\
\hline TST area (\%) & $\begin{array}{c}\text { Mean } \pm S D \\
\text { (range) }\end{array}$ & $\begin{array}{c}n=20 \\
89.2 \pm 18.3 \\
(39.9-110.3)\end{array}$ & $\begin{array}{c}n=22 \\
90.5 \pm 18.1 \\
(28.8-117.2)\end{array}$ & $\begin{array}{c}n=42 \\
89.9 \pm 17.9 \\
(28.8-117.2)\end{array}$ \\
\hline
\end{tabular}

\section{Supplementary Table 3: Electrophysiological scores.}

$\mathrm{CMCT}=$ central motor conduction time; $\mathrm{TST}=$ triple stimulation technique . 


\begin{tabular}{|c|c|c|c|c|c|c|c|c|}
\hline & & EDSS & PyEDSS & MSWS12 & 9HPT & 6MWT & 25FTW & AMSQ \\
\hline \multirow{4}{*}{ FA } & $\begin{array}{l}\text { Whole } \\
\text { Cord }\end{array}$ & $\begin{array}{l}r=-0.155 \\
p=0.321\end{array}$ & $\begin{array}{l}r=0.067 \\
p=0.669\end{array}$ & $\begin{array}{l}r=-0.206 \\
p=0.185\end{array}$ & $\begin{array}{l}r=0.273 \\
p=0.077\end{array}$ & $\begin{array}{l}r=0.124 \\
p=0.428\end{array}$ & $\begin{array}{l}r=-0.043 \\
p=0.782\end{array}$ & $\begin{array}{l}r=-0.146 \\
p=0.516\end{array}$ \\
\hline & Cord CST & $\begin{array}{l}r=-0.073 \\
p=0.641\end{array}$ & $\begin{array}{l}r=-0.007 \\
p=0.964\end{array}$ & $\begin{array}{l}r=-0.212 \\
p=0.171\end{array}$ & $\begin{array}{l}r=0.157 \\
p=0.314\end{array}$ & $\begin{array}{l}r=0.022 \\
p=0.889\end{array}$ & $\begin{array}{l}r=0.012 \\
p=0.937\end{array}$ & $\begin{array}{l}r=0.042 \\
p=0.854\end{array}$ \\
\hline & Brain All & $\begin{array}{l}r=-0.004 \\
p=0.980\end{array}$ & $\begin{array}{l}r=0.013 \\
p=0.933\end{array}$ & $\begin{array}{l}r=-0.047 \\
p=0.764\end{array}$ & $\begin{array}{l}r=-0.367 \\
p=0.016\end{array}$ & $\begin{array}{l}r=-0.116 \\
p=0.460\end{array}$ & $\begin{array}{l}r=0.097 \\
p=0.535\end{array}$ & $\begin{array}{l}r=-0.230 \\
p=0.303\end{array}$ \\
\hline & Brain CST & $\begin{array}{l}r=-0.077 \\
p=0.622\end{array}$ & $\begin{array}{l}r=-0.060 \\
p=0.703\end{array}$ & $\begin{array}{l}r=-0.277 \\
p=0.073\end{array}$ & $\begin{array}{l}r=-0.070 \\
p=0.654\end{array}$ & $\begin{array}{l}r=-0.076 \\
p=0.626\end{array}$ & $\begin{array}{l}r=0.004 \\
p=0.982\end{array}$ & $\begin{array}{l}r=0.115 \\
p=0.611\end{array}$ \\
\hline \multirow{4}{*}{ RD } & Whole cord & $\begin{array}{l}r=0.036 \\
p=0.819\end{array}$ & $\begin{array}{l}r=-0.137 \\
p=0.380\end{array}$ & $\begin{array}{l}r=0.100 \\
p=0.524\end{array}$ & $\begin{array}{l}r=-0.288 \\
p=0.061\end{array}$ & $\begin{array}{l}r=-0.034 \\
p=0.830\end{array}$ & $\begin{array}{l}r=-0.037 \\
p=0.816\end{array}$ & $\begin{array}{l}r=0.058 \\
p=0.796\end{array}$ \\
\hline & Cord CST & $\begin{array}{l}r=-0.026 \\
p=0.871\end{array}$ & $\begin{array}{l}r=-0.033 \\
p=0.835\end{array}$ & $\begin{array}{l}r=0.168 \\
p=0.282\end{array}$ & $\begin{array}{l}r=-0.151 \\
p=0.332\end{array}$ & $\begin{array}{l}r=-0.002 \\
p=0.989\end{array}$ & $\begin{array}{l}r=-0.040 \\
p=0.798\end{array}$ & $\begin{array}{l}r=-0.160 \\
p=0.477\end{array}$ \\
\hline & Brain All & $\begin{array}{l}r=-0.068 \\
p=0.666\end{array}$ & $\begin{array}{l}r=-0.027 \\
p=0.896\end{array}$ & $\begin{array}{l}r=-0.158 \\
p=0.313\end{array}$ & $\begin{array}{l}r=0.226 \\
p=0.145\end{array}$ & $\begin{array}{l}r=0.290 \\
p=0.059\end{array}$ & $\begin{array}{l}r=-0.184 \\
p=0.238\end{array}$ & $\begin{array}{l}r=0.230 \\
p=0.303\end{array}$ \\
\hline & Cord CST & $\begin{array}{l}r=0.012 \\
p=0.940\end{array}$ & $\begin{array}{l}r=0.037 \\
p=0.812\end{array}$ & $\begin{array}{l}r=0.155 \\
p=0.320\end{array}$ & $\begin{array}{l}r=-0.004 \\
p=0.979\end{array}$ & $\begin{array}{l}r=0.081 \\
p=0.604\end{array}$ & $\begin{array}{l}r=0.005 \\
p=0.976\end{array}$ & $\begin{array}{l}r=0.130 \\
p=0.564\end{array}$ \\
\hline \multirow{4}{*}{$A D$} & Cord All & $\begin{array}{l}r=-0.056 \\
p=0.722\end{array}$ & $\begin{array}{l}r=0.002 \\
p=0.990\end{array}$ & $\begin{array}{l}r=0.004 \\
p=0.978\end{array}$ & $\begin{array}{l}r=-0.083 \\
p=0.596\end{array}$ & $\begin{array}{l}r=0.026 \\
p=0.867\end{array}$ & $\begin{array}{l}r=-0.062 \\
p=0.691\end{array}$ & $\begin{array}{l}r=-0.059 \\
p=0.793\end{array}$ \\
\hline & Cord CST & $\begin{array}{l}r=-0.054 \\
p=0.729\end{array}$ & $\begin{array}{l}r=-0.007 \\
p=0.965\end{array}$ & $\begin{array}{l}r=0.074 \\
p=0.639\end{array}$ & $\begin{array}{l}r=0.003 \\
p=0.982\end{array}$ & $\begin{array}{l}r=0.046 \\
p=0.768\end{array}$ & $\begin{array}{l}r=-0.053 \\
p=0.734\end{array}$ & $\begin{array}{l}r=-0.065 \\
p=0.772\end{array}$ \\
\hline & Brain All & $\begin{array}{l}r=-0.099 \\
p=0.528\end{array}$ & $\begin{array}{l}r=-0.030 \\
p=0.851\end{array}$ & $\begin{array}{l}r=-0.238 \\
p=0.124\end{array}$ & $\begin{array}{l}r=0.214 \\
p=0.168\end{array}$ & $\begin{array}{l}r=0.334 \\
p=0.028\end{array}$ & $\begin{array}{l}r=-0.206 \\
p=0.184\end{array}$ & $\begin{array}{l}r=0.195 \\
p=0.383\end{array}$ \\
\hline & Brain Cst & $\begin{array}{l}r=-0.298 \\
p=0.052\end{array}$ & $\begin{array}{l}r=-0.226 \\
p=0.144\end{array}$ & $\begin{array}{l}r=-0.272 \\
p=0.077\end{array}$ & $\begin{array}{l}r=-0.179 \\
p=0.251\end{array}$ & $\begin{array}{l}r=0.162 \\
p=0.300\end{array}$ & $\begin{array}{l}r=-0.097 \\
p=0.537\end{array}$ & $\begin{array}{l}r=0.126 \\
p=0.576\end{array}$ \\
\hline
\end{tabular}

Supplementary Table 4: Correlation coefficients and $p$ values between DTI parameters and clinical scores. $\mathrm{CST}=$ corticospinal tract; FA = fractional anisotropy; $\mathrm{RD}=$ radial diffusivity; $\mathrm{AD}=$ axial diffusivity; EDSS = Expanded Disability Status Scale; T25FW = Timed 25-Foot Walk Test; 9HPT = 9-Hole Peg Test; 6MWT =6Minute Walking Test; MSW12 = MS Walking Scale; AMSQ = Arm Function in MS Questionnaire. 
40

\begin{tabular}{|c|c|c|c|c|c|c|}
\cline { 2 - 7 } & EDSS & pyEDSS & MSW12 & 9HPT & 6 MWT & $25 \mathrm{FTW}$ \\
\hline CMCT & 0.303 & $\mathbf{0 . 3 8 3}$ & $\mathbf{0 . 4 1 4}$ & 0.193 & -0.190 & 0.383 \\
& $p=0.051$ & $p=0.012$ & $p=0.006$ & $p=0.221$ & $p=0.229$ & $p=0.012$ \\
\hline TST ratio & -0.320 & -0.468 & -0.098 & 0.088 & 0.085 & -0.026 \\
& $p=0.039$ & $p=0.002$ & $p=0.538$ & $p=0.579$ & $p=0.592$ & $p=0.872$ \\
\hline \multirow{2}{*}{ TST area } & -0.303 & -0.548 & -0.143 & $0.293 \quad p=$ & 0.136 & -0.069 \\
& $p=0.052$ & $p<0.001$ & $p=0.365$ & 0.60 & $p=0.391$ & $p=0.665$ \\
\hline
\end{tabular}

\section{Supplementary Table 5: Correlations between electrophysiological and clinical data.}

Significant values are indicated in bold. pyEDSS = pyramidal EDSS; T25FW $=$ Timed 25-Foot Walk Test; 9HPT $=$ 9-Hole Peg Test; 6MWT = 6-Minute Walking Test; MSW12 = MS Walking Scale; AMSQ = Arm Function in MS Questionnaire. 


\section{Appendix for MRI methodology}

for

Joint assessment of brain and spinal cord motor tract damage in patients with early RRMS:

predominant impact of spinal cord lesions on motor function

\section{1/ Hardware}

Siemens MAGNETOM Verio (VB17) 3T

Coil head and surface (number of coil channels: 12, 32)

\section{2/ Acquisitions sequences}

\section{D FLAIR}

Acquisition time $=5 \mathrm{~min}$

Orientation $=$ Sagittal

Voxel size $=1 \times 1 \times 1.1$

$T R=5000$

$\mathrm{TE}=399$

$\mathrm{TI}=1800$

Flip angle $=120$

Field of view $=256 \times 256$

Matrix size $=256 \times 256$

\section{DT1}

Acquisition time $=4: 30$

Orientation $=$ Sagittal

Voxel size $=1 \times 1 \times 1$

$T R=1900$

$\mathrm{TE}=2.26$

$\mathrm{Tl}=900$

Flip angle=9

Field of view $=256 \times 256$

Matrix size $=256 \times 256$

Acquisitions both (pre and post Gd) Contrast enhancement

Axial T2

Acquisition time $=2: 12$ 


\begin{tabular}{|c|}
\hline Orientation $=$ Axial \\
\hline Voxel size $=0.7 \times 0.7 \times 3$ \\
\hline$T R=6530$ \\
\hline $\mathrm{TE}=9.4 / 84$ \\
\hline Flip angle $=148$ \\
\hline Field of view=220×165 \\
\hline Matrix size $=320 \times 240$ \\
\hline DTI-Single-shot GRE EPI \\
\hline Acquisition time $=5: 47$ \\
\hline Orientation=Sagittal \\
\hline Voxel size $=2 \times 2 \times 2$ \\
\hline $\mathrm{TR}=11000$ \\
\hline $\mathrm{TE}=82$ \\
\hline $\mathrm{b} \min / \mathrm{b} \max =0 / 1000$ \\
\hline Number of directions $=30$ \\
\hline Flip angle $=90$ \\
\hline Field of view $=256 \times 256$ \\
\hline Matrix size $=128 \times 128$ \\
\hline
\end{tabular}

Spinal cord acquisition sequence Axial T2*W MEDIC

2 acquisitions $=\mathrm{C} 1-\mathrm{C} 3$ and $\mathrm{C} 4-\mathrm{C} 7$

Acquisition time=twice $4 \mathrm{~min}$

Orientation=Axial

Voxel size $=0.7 \times 0.7 \times 3$

$\mathrm{TR}=849$

$\mathrm{TE}=23$

Flip angle $=30$

Field of view $=180 \times 180$

Matrix size $=256 \times 256$

Spinal cord acquisition sequence Sag T2

2 acquisitions = Cervical and Dorsal

Acquisition time $=3 \mathrm{~min}$ each

Orientation $=$ Sagittal

Voxel size $=0.9 \times 0.7 \times 2.5$

$\mathrm{TR}=3000$

$\mathrm{TE}=68$

Flip angle $=180$ 


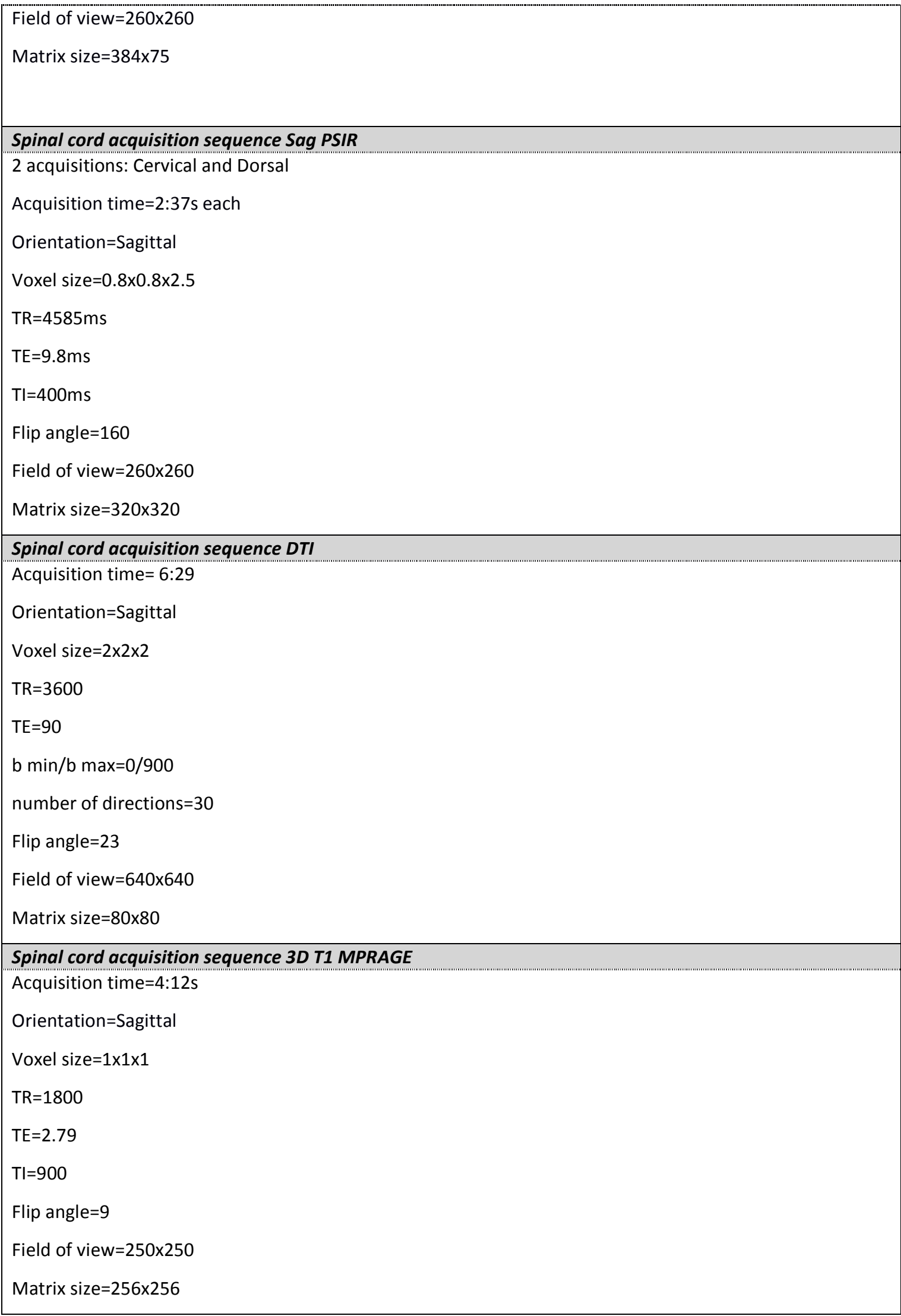




\section{3/ Image analysis methods and outputs}

\section{Brain Lesions}

Brain lesion T2-hyperintense lesions were defined as abnormal areas of increased signal change that could be demarcated from the surrounding tissue on 3D FLAIR images. axial T2 weighted images and axial PD weighted images were used to help lesion identification but the final delineation was manually performed by $\mathrm{RC}$ and $\mathrm{AK}$ on the axial $\mathrm{T} 2 *$ images.

\begin{tabular}{l|l|}
\hline $\begin{array}{l}\text { Analysis software } \\
\text { Output measure }\end{array}$ & ITK-snap (http://www.itksnap.org/) \\
\hline Spinal cord lesions & Brain lesion location, count and volume $\left(\mathrm{mm}^{3}\right)$ \\
\hline $\begin{array}{l}\text { Focal spinal cord T2-hyperintense lesions were defined as abnormal areas of increased signal change that } \\
\text { could be demarcated from the surrounding tissue on axial T2* images. Sagittal T2 weighted images and } \\
\text { sagittal PSIR images were used to help lesion identification but the final delineation was manually } \\
\text { performed by RC and AK on the axial T2* images. }\end{array}$
\end{tabular}

\begin{tabular}{|c|c|}
\hline Analysis software & ITK-snap (http://www.itksnap.org/) \\
\hline Output measure & Cervical spinal cord lesion location, count and volume $\left(\mathrm{mm}^{3}\right)$ \\
\hline \multicolumn{2}{|c|}{ Brain DTI motion and distortion correction } \\
\hline \multicolumn{2}{|c|}{$\begin{array}{l}\text { Motion and distortion correction with animaDiffusionlmagePreprocessing using images with reversed } \\
\text { phase encoding directions (antero-posterior and posterior-anterior) }\end{array}$} \\
\hline Analysis software & Anima (https://github.com/Inria-Visages/Anima-Public) \\
\hline Output & $\begin{array}{ll}\text { - } & \text { DTI images corrected } \\
\text { - } & \text { Estimated tensors map }\end{array}$ \\
\hline
\end{tabular}

\section{Brain cortical and white matter segmentation for Primary motor area segmentation}

Brain cortical parcellation on T1 3D brain images using FreeSurfer. Primary motor area considered was the pre and para central areas.

\begin{tabular}{|c|c|}
\hline Analysis software & FreeSurfer (https://surfer.nmr.mgh.harvard.edu/) \\
\hline Output & $\begin{array}{ll}\text { - } & \text { Seeds for probabilistic tractography } \\
\text { - } & \text { White matter masks }\end{array}$ \\
\hline \multicolumn{2}{|c|}{ Brain CST identification } \\
\hline $\begin{array}{l}\text { Brain portions } \\
\text { (animaDTIProbabi } \\
\text { Fibers were then } \\
\text { anterior pons, and }\end{array}$ & $\begin{array}{l}\text { the CSTs were identified using probabilistic tractography } \\
\text { actography) on DTI images after lesion removing and using motor cortex as seeds. } \\
\text { d through manually edited masks (ITK-snap) of brain pedoncula (left and right), } \\
\text { lla oblongata (left and right) }\end{array}$ \\
\hline
\end{tabular}

\begin{tabular}{|l|l|}
\hline Analysis software & $\begin{array}{l}- \text { Anima (https://github.com/Inria-Visages/Anima-Public) } \\
- \text { ITK-snap (http://www.itksnap.org/) }\end{array}$ \\
\hline Output & $-\quad$ Brain CSTs location and volume for each patients and each sides \\
\hline Brain and spinal cord DTI scalar maps \\
\hline $\begin{array}{l}\text { Fractional anisotropy (FA), axial (AD) and radial diffusivity (RD) maps were obtained from a tensor image } \\
\text { using animaComputeDTIScalarMaps and extracted on a set of prespecified ROIs. }\end{array}$ \\
\hline $\begin{array}{l}\text { Analysis software } \\
\text { Output }\end{array}$ & $\begin{array}{l}\text { Anima (https://github.com/Inria-Visages/Anima-Public) } \\
\text { mean FA, AD, RD for brain white matter, brain NASC, brain lesions and for } \\
\text { spinal cord, normal appearing SC and SC lesions. }\end{array}$ \\
\hline
\end{tabular}




\begin{tabular}{|c|c|}
\hline & - $\quad$ mean FA, AD, RD for brain and spinal cord CSTs. \\
\hline \multicolumn{2}{|c|}{ Distortion and motion correction of spinal cord DTI images } \\
\hline \multicolumn{2}{|c|}{ Motion and distortion correction of spinal cord DTI acquisition were performed using HySCO } \\
\hline Analysis software & - $\quad$ HySCO (http://www.diffusiontools.com/documentation/hysco.html) \\
\hline Output & $\begin{array}{l}\text { - } \quad \text { DTI images corrected } \\
\text { - } \quad \text { Estimated tensors map }\end{array}$ \\
\hline \multicolumn{2}{|c|}{ Cord segmentation and vertebrae levels labeling on Spinal cord axial T2* and DTI b=0 } \\
\hline \multicolumn{2}{|c|}{$\begin{array}{l}\text { The whole cord (WC) was segmented using the automatic sct_deepseg_sc command. Then, the vertebrae } \\
\text { were labeled using the sct_label_vertebrae command with initialization by selecting the axial slice that } \\
\text { passed through the center of the } \mathrm{C} 3 \mathrm{C} 4 \text { disc. }\end{array}$} \\
\hline Analysis software & - SCToolbox (https://sourceforge.net/p/spinalcordtoolbox/wiki/tools/) \\
\hline Output & - $\quad$ Spinal cord mask and vertebrae labels \\
\hline \multicolumn{2}{|c|}{ Identification of spinal cord CSTs Spinal cord axial T2* and DTI $b=0$ using atlas registration } \\
\hline \multicolumn{2}{|c|}{$\begin{array}{l}\text { Spinal cord CSTs were identified using registration (SCT_register_to_template) from MNI-poly-AMU } \\
\text { template to T2* and DTI b=0. } \\
\text { Spinal cord CSTs were identified from c1 to c6. }\end{array}$} \\
\hline Analysis software & - $\quad$ SCToolbox (https://sourceforge.net/p/spinalcordtoolbox/wiki/tools/) \\
\hline Output & $\begin{array}{l}\text { Spinal cord CSTs } \\
-\quad \text { lateral and ventral CSTs for axial T2* } \\
\text { - } \quad \text { lateral CSTs for DTI }\end{array}$ \\
\hline \multicolumn{2}{|c|}{ Alignment of spinal cord lesions on DTI images } \\
\hline \multicolumn{2}{|c|}{$\begin{array}{l}\text { Lesions mask was registered to } b=0 \text { DTI images using sct_register_multimodal with the help of spinal cord } \\
\text { segmentation already obtained from } s c t \text { deepseg_sc }\end{array}$} \\
\hline Analysis software & - $\quad$ SCToolbox (https://sourceforge.net/p/spinalcordtoolbox/wiki/tools/) \\
\hline Output & - $\quad$ Spinal cord lesions mask on DTI images \\
\hline \multicolumn{2}{|c|}{ Data extraction:lesion volume and mean DTI values } \\
\hline \multicolumn{2}{|c|}{$\begin{array}{l}\text { Mean DTI values were extracted using FSL on DTI scalar maps (FA, AD, RD) maps. } \\
\text { Lesions volume on brain, spinal cord and corresponding CSTs were extracted using FSL }\end{array}$} \\
\hline Analysis software & - FSL https://fsl.fmrib.ox.ac.uk/fsl/fslwiki \\
\hline Output & $\begin{array}{ll}- & \text { Mean DTI values } \\
\text { - } & \text { Lesions volume }\end{array}$ \\
\hline
\end{tabular}

\section{4/ Statistical analysis:}

Statistical analyses were performed with R 3.4.3. (https://cran.r-project.org/) 


\title{
Appendix for electrophysiology methodology \\ for
}

\author{
Joint assessment of brain and spinal cord motor tract damage in patients with early RRMS: \\ predominant impact of spinal cord lesions on motor function
}

Electrophysiological parameters were recorded using a Nicolet EDX apparatus (Natus Medical, Madison, Wisconsin, USA) and the dedicated software for Triple stimulation technique. A Magstim 200 Mono Pulse stimulator (maximum output $2.0 \mathrm{~T}$ ) with a circular coil (Magstim Company, Whitland, Wales, UK) was used for Transcranial Magnetic Stimulation (TMS). Recordings were performed on each side on the first dorsal interosseous muscle using surface electrodes. To account for a possible partial volume effect, the median nerve was stimulated simultaneously

${ }^{1}$. The peripheral stimuli were applied over the ulnar nerve at the wrist and over the brachial plexus (using monopolar stimulation) and the descending volleys were respectively denoted $\mathrm{CMAP}_{\text {Erb }}$ and $\mathrm{CMPAP}_{\text {wrist }}$.

Motor evoked potentials (MEP): The overall procedure for TMS followed recommendations of International Federation of Clinical Neurophysiology ${ }^{2}$. For TMS, the coil was first placed over the vertex then moved slightly in all directions until the position yielding the largest response was found. TMS pulses began at 30\% of the maximum output then were increased by steps of 10\% until TMS evoked consistently MEPs, usually 120\% of resting motor threshold. Latencies were determined with the shortest stable motor responses. Peripheral responses and MEPs were first elicited at rest for delay calculation. For some patients, facilitation maneuvers were needed to elicit MEPs (e.g slight contraction). In order to apply the same facilitation maneuvers during the peripheral stimulation than during TMS, strength contraction was monitored with audible surface electromyography.

MEP ratio was calculated as the baseline-to-peak amplitude of the MEP expressed as a percentage of the CMAP wrist $_{\text {. }}$ The central motor conduction time was calculated with the F-wave technique using the following formula : CMCT = cortical MEP latency - (F-wave latency + CMAP distal Latency - 1)/2

Triple stimulation technique : TST was performed according to the technique described by Magistris ${ }^{3}$. Briefly, the technique consists in three stimuli applied successively with precise time-intervals calculated using the following formulas:

Delay 1 (brain/distal nerve stimulations $)=$ minimum MEP latency $-\mathrm{CMAP}_{\text {wrist }}$

Delay 2 (proximal/distal nerve stimulations) $=\mathrm{CMAP}_{\mathrm{erb}}-\mathrm{CMAP}_{\text {wrist }}$

The $\mathrm{TST}_{\text {test }}$ curve was obtained with a first stimulation using cortical TMS that elicited descending volleys collided against elicited ascending volleys evoked at the ulnar wrist after Delay 1. A third stimulation at Erb's point, after a second interval corresponding to Delay 2, collided with the remaining ascending volleys. For the control conditions 
(TST $_{\text {control }}$ curve), the first stimulus was a sub maximal electrical stimulus applied at Erb's point and the second electrical stimulus at wrist was applied with Delay 2. The $\mathrm{TST}_{\text {test }}$ curve was compared with the TST $\mathrm{T}_{\text {control }}$ curve.

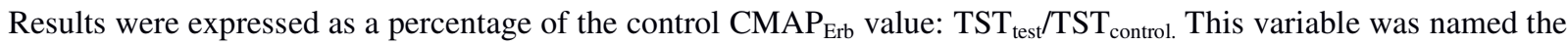
TST ratio $(\%)$ for the amplitude ratio and as TST area for the area ratio.

\section{References:}

1. Humm A M, Z’Graggen, W J, Von Hornstein, N E, Magistris M R, Rösler K M. Assessment of central motor conduction to intrinsic hand muscles using the triple stimulation technique: Normal values and repeatability. Clinical Neurophysiology 2004;115:2558-2566.

2. Rossini P M, Burke D, Chen R et al. Non-invasive electrical and magnetic stimulation of the brain, spinal cord, roots and peripheral nerves: Basic principles and procedures for routine clinical and research application: An updated report from an I.F.C.N. Committee. Clinical Neurophysiology, 2015;126(6):10711107.

3. Magistris M R, Rösler K M. Chapter 3 The triple stimulation technique to study corticospinal conduction. Supplements to Clinical Neurophysiology 2003; Vol. 56,Chapter 3. 


\section{Résumé}

Contexte: Bien que l'on soupçonne un impact cumulatif, l'effet des lésions du faisceau cortico-spinal (FCS) a été évalué séparément dans le cerveau et la moelle épinière chez les patients atteints de SEP. Objectif: Evaluer les dommages causés par les lésions de SEP sur le FCS encéphalique et médullaire cervical et examiner les associations relatives avec la fonction motrice, mesurée à la fois cliniquement et par électrophysiologie. Méthodes: Nous avons inclus 43 patients atteints de SEP rémittente récurrente diagnostiqué récemment. Les lésions ont été segmentées manuellement sur les IRM médullaire (T2 axiale *) et cérébral (3D FLAIR). Le FCS était automatiquement segmenté à l'aide d'un atlas (moelle) ou par tractographie (cerveau). Les fractions volumiques des lésions et les paramètres de diffusion ont été calculés pour la moelle, le cerveau et les FCS. La durée de conduction motrice centrale (CMCT) et le rapport d'amplitude mesuré par triple stimulation ont été mesurés pour 42 membres supérieurs, sur 22 patients. Résultats: Les fractions volumiques moyennes des lésions étaient de 5,2\% dans la partie médullaire du FCS et de 0,9\% dans la partie cérébrale. Nous n'avons pas trouvé de corrélation significative entre la fraction volumique des lésions du cerveau et de la moelle $(r=0,06, p=0,68)$. Le score EDSS pyramidal et le CMCT étaient tous deux corrélés de manière significative avec la fraction lésionnelle du FCS médullaire $(r=0,39, p=0,01$ et $\mathrm{r}=0,33, \mathrm{p}=0,03$ ) mais pas avec la fraction lésionnelle du FCS encéphalique. Conclusion: Nos résultats mettent en évidence la contribution majeure des lésions médullaires du FCS sur la fonction motrice.

\section{Abstract}

Background: In patients with MS, the effect of structural damage to the corticospinal tract (CST) has been separately evaluated in the brain and spinal cord (SC), even though a cumulative impact is suspected. Objective: To evaluate CST damages on both the cortex and cervical SC, and examine their relative associations with motor function, measured both clinically and by electrophysiology. Methods: We included 43 patients with early relapsing-remitting MS. Lesions were manually segmented on SC (axial T2*) and brain (3D FLAIR) scans. The CST was automatically segmented using an atlas (SC) or tractography (brain). Lesion volume fractions and diffusion parameters were calculated for SC, brain and CST. Central motor conduction time (CMCT) and triple stimulation technique amplitude ratio were measured for 42 upper limbs, from 22 patients. Results: Mean lesion volume fractions were $5.2 \%$ in the SC portion of the CST and $0.9 \%$ in the brain portion. We did not find a significant correlation between brain and SC lesion volume fraction $(r=0.06, p=0.68)$. The pyramidal EDSS score and CMCT were both significantly correlated with the lesion fraction in the SC CST $(r=0.39, p=0.01$ and $r=0.33, p=0.03)$, but not in the brain CST. Conclusion: Our results highlight the major contribution of SC lesions to CST damage and motor function abnormalities. 


\section{CHOUTEAU, Raphaël - Évaluation conjointe des lésions du tractus moteur du cerveau et de la moelle épinière chez les patients atteints de SEP débutante: impact prédominant des lésions de la moelle épinière sur la fonction motrice}

Feuilles : 47, illustrations : 3, tableaux : 11, 30 cm.- Thèse : Médecine ; Rennes 1; 2019 ; $\mathrm{N}^{\circ}$

\section{Résumé français}

Contexte: Bien que l'on soupçonne un impact cumulatif, l'effet des lésions du faisceau corticospinal (FCS) a été évalué séparément dans le cerveau et la moelle épinière chez les patients atteints de SEP.

Objectif: Evaluer les dommages causés par les lésions de SEP sur le FCS encéphalique et médullaire cervical et examiner les associations relatives avec la fonction motrice, mesurée à la fois cliniquement et par électrophysiologie.

Méthodes: Nous avons inclus 43 patients atteints de SEP rémittente récurrente diagnostiqué récemment. Les lésions ont été segmentées manuellement sur les IRM médullaire (T2 axiale ${ }^{*}$ ) et cérébral (3D FLAIR). Le FCS était automatiquement segmenté à l'aide d'un atlas (moelle) ou par tractographie (cerveau). Les fractions volumiques des lésions et les paramètres de diffusion ont été calculés pour la moelle, le cerveau et les FCS. La durée de conduction motrice centrale (CMCT) et le rapport d'amplitude mesuré par triple stimulation ont été mesurés pour 42 membres supérieurs, sur 22 patients.

Résultats: Les fractions volumiques moyennes des lésions étaient de 5,2\% dans la partie médullaire du FCS et de 0,9\% dans la partie cérébrale. Nous n'avons pas trouvé de corrélation significative entre la fraction volumique des lésions du cerveau et de la moelle $(r=0,06, p=0,68)$. Le score EDSS pyramidal et le CMCT étaient tous deux corrélés de manière significative avec la fraction lésionnelle du FCS médullaire $(r=0,39, p=0,01$ et $r=0,33, p=0,03)$ mais pas avec la fraction lésionnelle du FCS encéphalique. Conclusion: Nos résultats mettent en évidence la contribution majeure des lésions médullaires du FCS sur la fonction motrice.

Rubrique de classement: $\quad$ NEUROLOGIE

Mots-clés : Lésion T2, électrophysiologie, IRM, Moelle épinière

Mots-clés anglais MeSH : T2 lesions, electrophysiology, MRI, spinal cord, multiple sclerosis

\begin{tabular}{lll}
\hline JURY : & Président : & Monsieur Gilles EDAN
\end{tabular}

Assesseurs :

Mme Anne KERBRAT [directeur de thèse]

M. Paul SAULEAU

M. Jean-Christophe FERRE

M. Benoit COMBES 